\title{
A Review of Precision Technologies for Optimising Pasture Measurement on Irish Grassland
}

\author{
Darren J. Murphy ${ }^{1,2}$, Michael D. Murphy ${ }^{2}{ }^{\mathbb{D}}$, Bernadette $\mathrm{O}^{\prime}$ Brien $^{1}$ and Michael $\mathrm{O}^{\prime}$ Donovan ${ }^{1, *}$ \\ 1 Teagasc, Animal \& Grassland Research and Innovation Centre, Moorepark, Fermoy, Ireland; \\ darren.murphy@teagasc.ie (D.J.M.); bernadette.obrien@teagasc.ie (B.O.) \\ 2 Department of Process, Energy and Transport Engineering, Munster Technological University, Cork, Ireland; \\ michaeld.murphy@cit.ie \\ * Correspondence: michael.odonovan@teagasc.ie
}

Citation: Murphy, D.J.; Murphy, M.D.; O’Brien, B.; O’Donovan, M. A Review of Precision Technologies for Optimising Pasture Measurement on Irish Grassland. Agriculture 2021, 11, 600. https://doi.org/10.3390/ agriculture 11070600

Academic Editor: Dionissios Kalivas

Received: 7 June 2021

Accepted: 18 June 2021

Published: 28 June 2021

Publisher's Note: MDPI stays neutral with regard to jurisdictional claims in published maps and institutional affiliations.

Copyright: (c) 2021 by the authors. Licensee MDPI, Basel, Switzerland. This article is an open access article distributed under the terms and conditions of the Creative Commons Attribution (CC BY) license (https:// creativecommons.org/licenses/by/ $4.0 /)$.

\begin{abstract}
The development of precision grass measurement technologies is of vital importance to securing the future sustainability of pasture-based livestock production systems. There is potential to increase grassland production in a sustainable manner by achieving a more precise measurement of pasture quantity and quality. This review presents an overview of the most recent seminal research pertaining to the development of precision grass measurement technologies. One of the main obstacles to precision grass measurement, sward heterogeneity, is discussed along with optimal sampling techniques to address this issue. The limitations of conventional grass measurement techniques are outlined and alternative new terrestrial, proximal, and remote sensing technologies are presented. The possibilities of automating grass measurement and reducing labour costs are hypothesised and the development of holistic online grassland management systems that may facilitate these goals are further outlined.
\end{abstract}

Keywords: pasture-based agriculture; precision agriculture; remote sensing; spectroscopy; grass measurement; grassland sampling

\section{Introduction}

Demand for animal protein products is predicted to increase by $>70 \%$ in the coming decades as a consequence of the growing distribution of wealth in developing countries [1,2]. Consequently, this could potentially result in an $80 \%$ increase in agricultural GHG emissions, which would critically impact the environment if not mitigated [3]. Grassland based agriculture has a significant role to play in terms of increasing food production in an environmentally sustainable manner. Over recent decades, there has been a $30 \%$ decrease in European pasture land usage as a result of the increased levels in production efficiency and feed controllability that are achievable with confinement based systems, where animals are fed indoors [4,5]. Conversely, pasture-based systems in suitable climates have the potential to be more economically and environmentally sustainable than confinement systems. However, pasture-based systems are hindered by reduced feed controllability due to the spatial and temporal heterogeneity of grassland swards [6,7]. The quantity of herbage available for grazing within pastures can vary between $15 \%$ and $60 \%$ as a result of selective grazing, dung pats, and seasonal changes in sward morphology, making it difficult to accurately measure and allocate for grazing [8-10].

In Ireland, grazed grass is the predominant livestock feed source due to the suitability of the temperate climate for grass production [11]. The Irish climate provides optimum conditions for grazing, enabling cows to graze in excess of 300 days per year, which allows Ireland to produce milk and beef at a relatively low cost and in a sustainable manner $[12,13]$. Maximising pasture utilisation through optimal grassland management is vital in terms of ensuring the economic sustainability and mitigation of the environmental impact of pasture-based livestock production. A pasture-based system that can maintain 
concentrate and nitrogen $(\mathrm{N})$ fertilizer levels while increasing grass utilisation and stocking rate will increase $\mathrm{N}$ use efficiency [14,15]. Efficient and sustainable pasture-based livestock production is primarily based upon synchronising the herd's dietary requirements with seasonal grass production rates. This allows for the maximum level of fresh grass to be utilised through an increased daily intake of high-quality fresh grass dry matter (DM) per grazing animal [16,17]. Increasing grass utilisation has major financial benefits, as fresh grass is the cheapest feed source on Irish ruminant livestock farms [18]. Currently, the average Irish dairy farmer is utilising approximately $7-8 \mathrm{t} \mathrm{DM} \mathrm{ha}^{-1}$ of grass per annum, but has the potential to utilise 12-16 $\mathrm{t} \mathrm{DM} \mathrm{ha}^{-1}$ [19-21]. The value of increasing grass utilisation has been estimated to be up to $€ 173$ tonne $^{-1}$ ha $^{-1}$ year $^{-1}$ [17]. Frequent and accurate measurement of grass quantity and quality is one of the main methods of maximising grass utilisation and production on pasture-based farms [20,22,23]. Optimal grassland management is highly dependent on the accuracy of information on pasture quantity and quality that is available to the farmer [16,24]. Precise grass allocation to the herd is integral to optimal grassland management. Excess allocation of grass leads to wastage and quality degradation within a pasture. Alternatively, not providing sufficient herbage to the herd results in decreased milk and beef production [25]. Grass is quantified and allocated in terms of herbage mass (HM), which is the unit weight of DM per hectare $\left(\mathrm{ha}^{-1}\right)$ and is measured in units of $\mathrm{kg} \mathrm{DM} \mathrm{ha}{ }^{-1}$.

Several non-destructive methods and tools for measuring grass quantity have become popular on Irish farms in recent decades. There are a range of issues with these methods with regard to operator bias, precision, and difficulties in accounting for spatial variation [26-28]. Another significant issue concerning current grass measurement practices is the absence of a definitive protocol for grass measurement that farmers can use to objectively measure their grass and to account for the variation of grass growth within paddocks [29].

In terms of grass quality, there are no established on-farm methods which a farmer can use to estimate the quality of grass within their pasture. Pasture qualitative analysis methods are typically laboratory based and involve time consuming pre-processing procedures, such as grinding and oven drying, which can take several days to complete. Grass quality parameters that are considered important for grazing systems include DM, dry matter digestibility (DMD), metabolisable energy (ME), organic matter digestibility (OMD), crude protein (CP) and water-soluble carbohydrates (WSC) [11,30]. Significant potential exists for improving the availability and accuracy of grassland measurement information by means of precision agriculture (PA) technologies. The concept of PA is focused on the acquisition of precise field data at a spatial and temporal scale that would capture pasture variation and enable targeted responses, with the aim of increasing economic returns and reducing environmental impacts [31]. Precision technologies are a relatively new phenomenon with regard to grassland management compared with larger, more industrial scale agri-systems such as cropland industries [24]. Schellberg et al. [31] outlined reasons for the comparatively slow uptake of PA technologies with regard to grassland farming. The most significant factors included the greater diversity within grassland, in terms of the spatial variation of soil and pasture characteristics, and the highly temporal dynamics of grass species.

The aim of this review is to present an overview of the most seminal research pertaining to recent precision grassland measurement technological developments. The development of such technologies will be integral to achieving sustainable growth in grassland livestock industries in the future. This review is primarily focused on grass measurement systems that may be suitable for pasture-based livestock systems situated in temperate regions such as Ireland, although the research discussed is also applicable to global pasturebased industries. There has been no recent review of grass measurement technological developments relevant to Irish grassland. Relevant literature was initially collected using online databases prior to manual screening to select the most seminal research for inclusion in this review. 
The first section of this review outlines the methodology used to select the literature discussed in the subsequent sections. Secondly, significant factors pertaining to grassland sward heterogeneity, conventional grass measurement methods, and the principles of pasture sampling will be discussed. Thirdly, this review will focus on state-of-the-art research on precision grassland measurement technologies. Finally, current challenges facing the development of precision grass measurement systems and the future of grassland measurement will be discussed.

\section{Review Search Methodology and Literature Summary}

Searches for seminal literature were performed on Google Scholar [32] and ScienceDirect [33] using the following keywords: grass measurement, pasture, remote sensing, temperate grassland, perennial rye grass, clover, grassland heterogeneity, spectroscopy. Initially, studies from the period of 1970-2021 were selected $(n=313)$ to track developments in conventional grass measurement over the past 50 years and provide the context for the initial sections of this review. A subset of more recent studies from the period between 2001-2021 ( $n=47$ ) was then selected to identify seminal research relating to state-of-the-art developments in grass measurement technology, which are discussed in the latter sections of this review. The literature dataset was then manually refined to exclude non relevant and duplicate studies. Inclusion criteria were: studies must contain original peer-reviewed research and be published as either scientific journal articles or conference papers; research was conducted on temperate pasture, preferably including perennial rye grass perennial ryegrass (Lolium perenne L.) (PRG) and/or white clover (Trifolium repens L.; clover) (WC) and articles were in the English language. Exclusion criteria included research conducted on arid or tropical grassland with no relevance to Irish pasture and studies that had insufficient information regarding the error of assessed measurement systems. Additional studies were located by tracking references and citations from the most relevant literature in the initial dataset. The refined literature dataset contained $n=99$ studies relating to the measurement of temperate grassland. A summary of the dataset indicating the technologies used, region, grass species and scale of the selected studies can be viewed in Appendix A. The selected studies are discussed in the following sections of this review.

\section{Grassland Sward Heterogeneity}

The availability of herbage for grazing can vary considerably within pastures, which makes it difficult to accurately quantify and allocate on a regular basis. Sward heterogeneity in terms of both quantity and quality can increase as a result of a number of factors, including soil, environmental, temporal, compositional, and grazing conditions. Jordan et al. [34] recorded mean variation in HM to be in the range of 15-30\% on intensively cut PRG dominant silage fields in the North of Ireland. This study further recorded increases in sward variation as the growing season progressed in accordance with the morphological growth stages of PRG. Heterogeneity is typically higher within grazed pastures compared with silage fields, due to selective grazing by animals, which increases the difficulty of estimating average HM [9]. Barthram et al. [8] recorded variation in sward height in the range of 30-70\% due to selective grazing on PRG dominant swards grazed by sheep in Scotland. Klootwijk et al. [9] quantified that the area of rejected patches of pasture ranged from $22 \%$ to $43 \%$, which increased as the grazing season progressed in Dutch PRG pastures, and recommended that the area of rejected patches be accounted for when calculating available HM. Murphy et al. [35] found that average pre-grazing HM variation was 36\% over a grazing season within Irish PRG dominant dairy pastures. A summary of reported values of sward heterogeneity in terms of grass quantity can be seen in Table 1.

A further cause of pasture variation and damage is poaching. In wet conditions, treading pressure from animals remoulds the soil surface damaging the sward and compacting the soil, which can increase weed ingress and reduce pasture production. Grassland management factors, such as stocking rate and herbage allowance, also have significant impacts on the variation of sward yield and quality within a pasture [36]. Sward composition, in 
terms of both species and morphology, is another significant factor with regard to pasture heterogeneity. Mixed swards of WC and PRG are becoming more popular on Irish farms due to their noted environmental and grazing benefits $[37,38]$. Clover has a lower canopy height than PRG, resulting in mixed swards having greater variation in canopy surface height, which can make measurement more difficult [39]. Multi-species swards, including plants such as chicory (Cichorium intybus L.) and plantain (Plantago lanceolata L.), may become more frequently used on grassland pastures in the near future with the objectives of increasing quality and reducing $\mathrm{N}$ requirements [40]. Similar to PRG/WC swards, multi-species swards may have greater variation in canopy height and structure compared with PRG monocultures. Furthermore, the morphological growth stage of the PRG plant has a major effect on sward structure and variation. The main components of the PRG plant (leaf, stem, and dead leaf proportions) vary considerably depending on the morphology of the plant, time of year, and grazing management [41]. Temporal and morphological effects have further significant impacts on sward quality variation. Wilkinson et al. [23] found that variation in most sward quality components increased rapidly as the sward entered its reproductive growth stage, with variation at a maximum in the middle of the grazing season in British pastures. The study also found that within month variation in sward quality was large, resulting in either inadequate or excessive amounts of essential nutrients being provided to grazing animals and recommended that regular sward quality measurements be taken to allow for more optimum feeding of animals.

Table 1. Summary of reported values of mean sward heterogeneity in terms of pre-grazing grass quantity on temperate grasslands.

\begin{tabular}{ccccccc}
\hline Study & Year & $\begin{array}{c}\text { Grass } \\
\text { Species }\end{array}$ & Region & Sward Type & $\begin{array}{c}\text { Measurement } \\
\text { Parameter }\end{array}$ & $\begin{array}{c}\text { Sward } \\
\text { Heterogeneity * }\end{array}$ \\
\hline Murphy et al. [29] & 2020 & PRG/WC & Ireland & Dairy pasture & HM $\left(\mathrm{kg} \mathrm{DM} \mathrm{ha}^{-1}\right)$ & $36 \%$ \\
\hline Jordan et al. [34] & 2003 & PRG & Ireland & Silage field & HM $\left(\mathrm{kg} \mathrm{DM} \mathrm{ha}^{-1}\right)$ & $25 \%$ \\
\hline Murphy et al. [29] & 2020 & PRG/WC & Ireland & Dairy pasture & CSH $(\mathrm{mm})$ & $29 \%$ \\
\hline Klootwijk et al. [9] & 2019 & PRG & The Netherlands & Dairy pasture & CSH (mm) & $28 \%$ \\
\hline Barthram et al. [8] & 2005 & PRG/WC & Scotland & Sheep pasture & Height $(\mathrm{mm})$ & $46 \%$ \\
\hline
\end{tabular}

* Sward heterogeneity = coefficient of variation of measurement parameter, $\mathrm{HM}=$ herbage mass, $\mathrm{CSH}=\mathrm{compressed}$ sward height, Height

= standing sward height, $\mathrm{PRG}=$ perennial rye grass, $\mathrm{WC}=$ white clover.

\section{Conventional Grass Measurement}

Destructive measurement refers to when herbage is cut and removed from the pasture for direct analysis. Destructive techniques are typically used as reference methods for modelling herbage parameters by means of non-destructive measurement methods. The 'gold standard' method of determining HM is by cutting and weighing herbage samples using a quadrat, shears, and scales [16,42]. Despite cutting and weighing being the reference method for determining HM there are numerous potential sources of measurement error including operator bias regarding sample area selection and post cutting height. Furthermore, there are several well documented disadvantages to cutting and weighing including labour intensity and herbage destruction [42-44]. A significant disadvantage of cutting and weighing is the requirement of a large number of samples to account for sward spatial variation within grazed pastures. Sward heterogeneity can be accounted for by increasing sampling intensity. However, this leads to increases in measurement labour and time, as well as increases in the quantity of herbage removed from the pasture [45-47].

Non-destructive measurement refers to when grass is analysed in-situ and modelling techniques are used to predict selected parameters. This form of measurement enables realtime analysis of pasture and ultimately allows for more responsive grassland management decision making. Non-destructive measurement techniques are typically cheaper, less laborious, and more practical than destructive methods. For these reasons non-destructive 
techniques are more commonly used by farmers on a regular basis. However, modelling techniques are prone to error and non-destructive methods are typically less accurate than destructive methods.

Visual estimation is the most fundamental method of non-destructive grass measurement. It involves the farmer observing the pasture and estimating the average HM within a paddock. It is the fastest, cheapest, and least laborious method of measuring HM. The farmer is able to use their knowledge of the sward's composition to account for the variation in HM within the pasture $[48,49]$. The most significant issue with visual estimation is that it is highly subjective and variations in herbage estimations between observers have been noted to be large [50-52].

The most established non-destructive tool for measuring pasture in Ireland is the rising plate meter (RPM) [20,29]. The RPM records a combined measure of pasture height and density, referred to as compressed sward height (CSH), using a weighted disc attached to a scaled staff that is dropped onto the sward. Recorded CSH is then used to model $\mathrm{HM}$. Use of the RPM requires minimal training and a large number of samples can be recorded and distributed throughout a paddock in a relatively short time duration [53,54]. A recent iteration of the RPM has been developed in Ireland [55] that uses a GPS integrated ultrasonic sensor to record the height of the rising plate (Figure 1). The main advantages of this RPM over conventional models are its rapid data processing capabilities via automated links to online decision support tools (DST) and its ability to geo-tag measurement data.

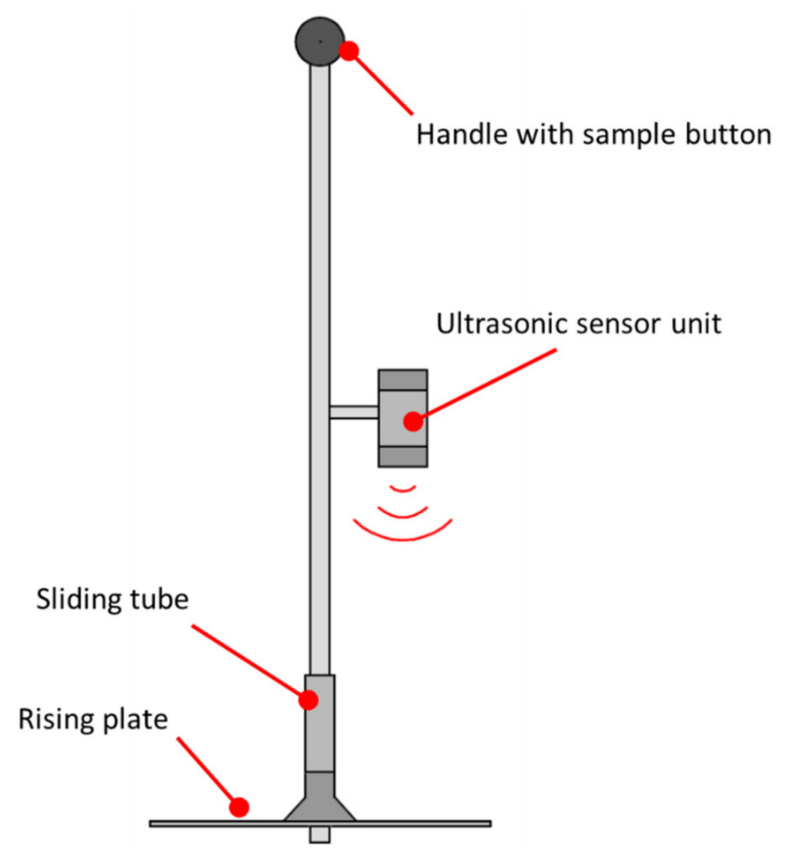

Figure 1. Schematic of ultrasonic rising plate meter developed by McSweeney et al. [55].

Despite the RPM being an established grass measurement tool, its limitations in terms of accuracy have been noted. A considerable source of RPM error is the large variation between CSH measurements recorded within pastures, resulting from the interaction between the rising plate and the heterogeneity of the vertical profile of the sward. Factors reported to affect this interaction include grass species, season, and grazing intensity $[28,47,56]$. There is no standardised RPM design and models vary considerably in terms of plate pressure and measurement system. This makes it difficult to transfer established HM calibrations between different RPM models [57]. Despite the RPM being designed to reduce the subjectivity of grass measurement, there is no robust measurement protocol on how to use the RPM in an objective manner and this can contribute to measurement variation. A recent study by Togeiro de Alckmin et al. [58] on controlled PRG trial plots in Tasmania found that the RPM had a root mean square error (RMSE) of $522 \mathrm{~kg} \mathrm{DM} \mathrm{ha}^{-1}$. A similar 
study in Ireland on PRG dominant trial plots and grazed paddocks reported RPM errors of $354 \mathrm{~kg} \mathrm{DM} \mathrm{ha}^{-1}$ and stated that this error could be reduced to $243 \mathrm{~kg} \mathrm{DM} \mathrm{ha}^{-1}$ by combining RPM measurement with grassland management and meteorological data by means of machine learning [59]. The study further included a comprehensive review of RPM HM prediction error and its sources. A further study estimated the combined effects of both measurement and calibration error for the RPM to be $28.1 \%$ relative prediction error (RPE), when a robust measurement protocol was adhered to [35].

\section{Pasture Sampling Techniques}

To account for pasture heterogeneity multiple samples or measurements may need to be taken at locations distributed throughout a paddock following a predetermined protocol $[34,45,60]$. The effectiveness of a sampling protocol can be defined by its accuracy, precision, and level of potential bias [43]. To determine an absolute mean parameter value for a pasture, the entirety of the herbage within that pasture would need to be harvested and analysed. This may be possible on small, controlled trial plots used in research but is not practical on grazed paddocks. Therefore, the best possible representation of the absolute mean must be determined, henceforth referred to as the 'true' mean. Accurately estimating the 'true' mean of any herbage parameter can be difficult owing to the heterogeneous nature of grazed swards.

A significant source of measurement error is inconsistent operator use, which is defined in terms of reproducibility or operator bias [61]. Bias error can be minimised by adhering to a robustly designed sampling protocol. Once a pasture measurement tool is used in accordance with manufacturer guidelines, bias in terms of sample area selection remains the greatest source of unknown bias. For example, when measuring a pasture area, an operator may select the shortest path between the pasture entry and exit points and take all of their samples along this path, as this is most convenient. This path may not give an accurate representation of the variation of herbage within the pasture and is therefore biased by the operator's desire for convenience. Likewise, the operator may consciously or subconsciously select sample locations with either consistently high or low proportions of herbage. Similarly, an operator might choose to sample a paddock along transect lines (Figure 2a) in an attempt to distribute samples more evenly. This method is also biased by the operators preference with regard to the positioning of each transect line. There is no definitive protocol for objective pasture sampling or measurement on Irish pastures. With regard to the RPM, measurements are typically carried out 25-50 times in transects or in a ' $W$ ' pattern (Figure 2b) throughout a paddock [27,43,52]. To avoid operator bias and maximise measurement precision, sample locations should be randomly selected and spatially balanced throughout a pasture, although this can be difficult to implement in practice. If sample location selections are totally random, the entire area within a paddock has an equal probability of selection. Measurement parameter values can be treated as random variables and statistical analysis can be employed to determine parameter mean and estimation error without bias [44,62].

Increasing sampling area and resolution may increase measurement precision, however, this further increases sampling time and cost. There is a trade-off between the benefit of increasing accuracy versus time and cost. Reducing measurement time and effort is vital, not only in saving labour costs for farmers, but also to encourage more farmers to measure grass on a regular basis. The time and cost requirements of regular and accurate grass measurement are significant barriers to promoting grass measurement on farms. A study conducted by Creighton et al. [21] showed that only $20 \%$ of Irish dairy farmers used technology to measure grass on a regular basis. Deming et al. [63], in a study of Irish dairy farms that were classified as labour efficient, found that farmers spent between 0.28 and $0.41 \mathrm{~h} \mathrm{cow}^{-1}$ year $^{-1}$ at grass measurement. Behavioural studies by Hall et al. [64] in Tasmania and Eastwood et al. [65] in New Zealand, reported that farmers reported a lack of confidence in accuracy and regarded measurement time and effort as major barriers to the adoption of measurement tools for pasture management. 

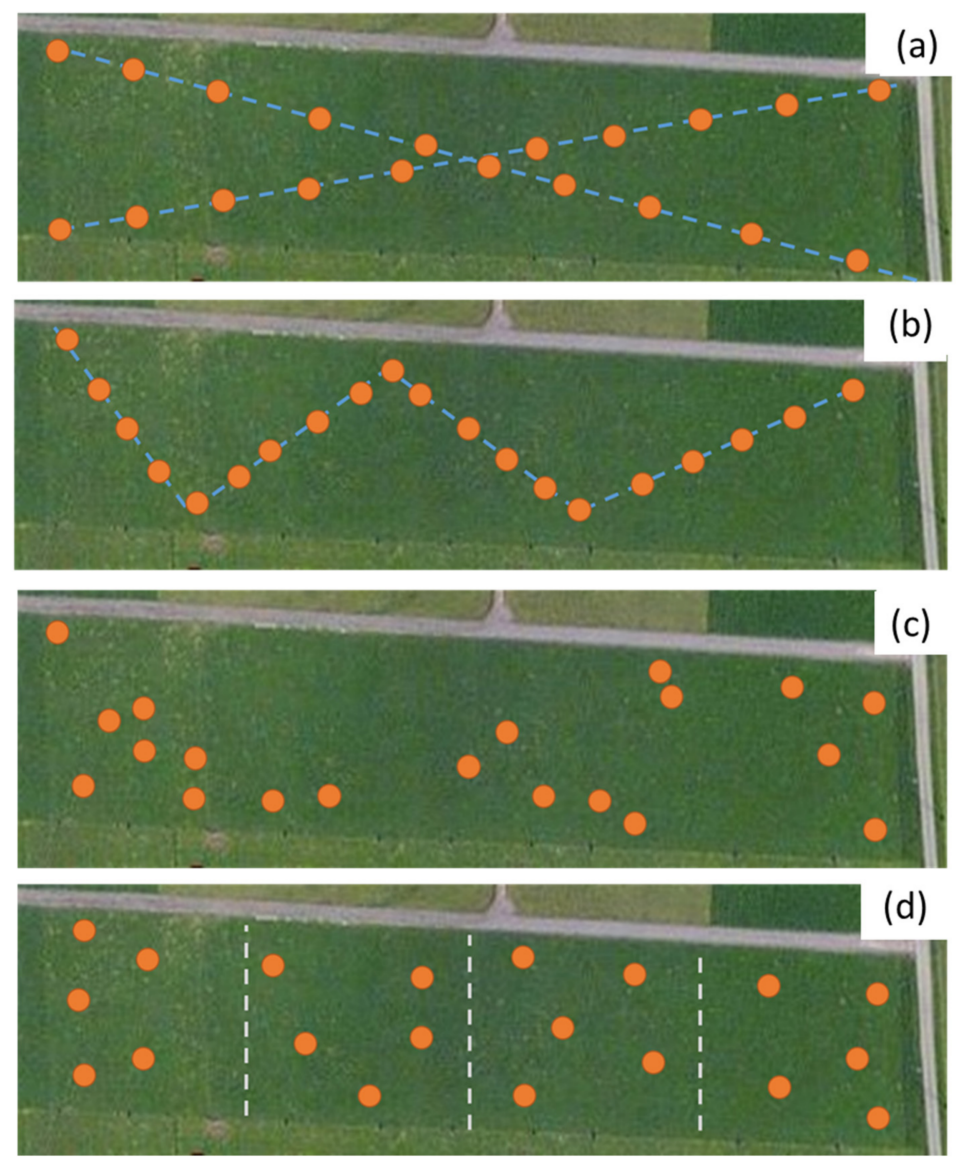

Figure 2. Illustration of (a) ' $\mathrm{X}$ ' transect; (b) 'lazy $\mathrm{W}^{\prime}$; (c) simple random; and (d) random stratified sampling pasture measurement protocols on 1 ha grazed pasture, with orange circles indicating measurement locations $(n=20)$ and blue dashed line outlining the measurement route for $(\mathbf{a})$ and $(\mathbf{b})$.

The requirement for the development of a universal pasture sampling methodology to reduce operator bias, give more precise representations of spatial variation, and minimise measurement labour has long been acknowledged [34,46,56]. O' Sullivan et al. [54] presented a combined technique of quadrat cuts and RPM measurements with the aim of reducing the number of herbage cuts required (by 50\%) to accurately predict 'true' HM for research purposes on Irish PRG pastures. Thomson et al. [52] outlined the need for HM measurement protocol standardisation between dairy research centres in New Zealand and recommended that 50-80 RPM measurements be taken per paddock. Nakagami [10] developed a method to assess HM in Japanese pastures by RPM sampling just two areas per paddock, but when validated on commercial paddocks, only half of the estimates were found to be within $20 \%$ of 'true' mean. Hutchinson et al. [66] prototyped a pasture sampling protocol for the RPM in the form of a decision tree that could be easily understood by farmers, outlining the required number of RPM measurements in relation to an operators desired level of precision. The study found that a depreciating exponential relationship existed between RPM measurement rate and HM prediction error and recommended random stratified sampling (RSS) as an accurate method of pasture sampling. Similar relationships between grass sampling rate and error have been reported by Jordan et al. [34], $\mathrm{O}^{\prime}$ Sullivan et al. [54], and Murphy et al. [29] on Irish PRG swards. Using quadrat cuts, Jordan et al., [34] recommended a sampling rate of 7 cuts ha $^{-1}$ based on the principle of RSS, to estimate 'true' mean HM to within 5\% error and enable yield mapping of spatial heterogeneity within silage fields. A study by Murphy et al. [35] utilised RSS to developed a grass measurement optimisation tool to generate accurate and efficient grass measurement protocols and concluded that eight measurements $\mathrm{ha}^{-1}$ was an optimum sampling rate for the RPM. 
The RSS method involves dividing the target measurement domain into several equally sized strata and then assigning an equal number of samples randomly within each stratum, as seen in Figure 2d. This allows for a more efficient distribution of samples within the domain in comparison with simple random sampling (Figure 2c) and average spatial variation within and across strata can be estimated without bias $[43,63,67]$. The implementation of robust sampling protocols in conjunction with GPS technology enables the use of geostatistical procedures such as Kriging interpolation, which can be used to develop parameter heat maps of a pasture for spatial analysis and PA applications [63,67]. Accurate geo-referenced measurement information of sward quantity and quality would enable the use of variable rate fertilisation systems to reduce cost, GHG emissions, and nutrient leaching to waterways. Moreover, such data could lead to more precise spatial analysis of sward characteristics and ultimately lead to increases in pasture utilisation $[24,68,69]$.

\section{Grass Quality Analysis by Means of Near Infrared Spectroscopy}

Most conventional grass quality measurement methods require herbage samples to be taken from the field and analysed in the laboratory. One of the more established and rapid methods of herbage quality analyses is near infrared spectroscopy (NIRS). Conventional lab-based NIRS required removal of herbage samples from the field and pre-processing of the samples prior to analyses. More recent NIRS developments have focused on reducing the need for sample removal and pre-processing. Sample removal can be avoided by means of in-situ or portable NIRS analysis. The main advantages of NIRS are that it is a more rapid analysis technique and it has no chemical input requirements compared with traditional wet chemistry analysis procedures. Disadvantages include the initial cost of purchasing an NIRS spectrometer and its reliance on chemometric modelling techniques, which are prone to error. Near infrared (NIR) light energy has characteristic wavelengths ranging between approximately 700 and $2500 \mathrm{~nm}$ on the electromagnetic spectrum [70,71]. Near infrared spectroscopy analysis measures the absorption rates of low energy infrared light radiation within matter, which are then used to quantify the chemical constituents of said matter by means of empirical modelling methods, referred to as chemometrics.

Analyses of dried and milled forage quality by means of NIRS is well established within the agri-food industry [72-74]. More recently, NIRS quality prediction calibrations have been derived for dried and milled grass for research purposes in Ireland, such as identifying desired traits for different grass varieties $[30,75,76]$. Recent research has focused on applying NIRS to predict quality parameters of fresh herbage with the aim of further reducing laboratory workloads by eradicating the need for sample pre-processing, which can also have detrimental effects on sample composition [77]. Spectroscopic analysis of fresh forages and grasses is largely restricted by the high presence of moisture, which results in large spectral peaks that overshadow spectral identifiers for numerous quality traits, such as CP [77-79]. Despite this, breakthroughs have been made with regard to NIRS analyses of fresh forage and grass using conventional NIR instruments. Thomson et al. [80] investigated if a pre-existing fresh grass silage NIRS calibration could predict quality in grass/clover silage samples in the UK. The study found that some parameters such as DMD could be predicted with acceptable accuracy. However, bias for parameters such as CP increased with clover content and clover specific calibrations performed better. Alomar et al. [81] concluded that reflectance NIRS could accurately predict the compositional components, including $\mathrm{DM}\left(\mathrm{R}^{2}=0.99, \mathrm{SE}=6.5 \mathrm{~g} \mathrm{~kg}^{-1}\right)(\mathrm{SE}=$ standard error) and $\mathrm{CP}\left(\mathrm{R}^{2}=0.91, \mathrm{SE}=18.4 \mathrm{~g} \mathrm{~kg}^{-1}\right)$, of a variety of fresh grass swards in Southern Chile. Dale et al. [82] developed fresh grass NIRS calibrations to investigate optimum sampling and storage techniques on Irish PRG dominant pastures and reported $\mathrm{R}^{2}$ values of $0.92\left(\mathrm{SE}=0.95 \mathrm{~g} \mathrm{~kg}\right.$ fresh weight $\left.{ }^{-1}\right), 0.90\left(\mathrm{SE}=0.543 \mathrm{~g} \mathrm{~kg}\right.$ fresh weight $\left.^{-1}\right)$ and $0.79\left(\mathrm{SE}=0.622 \mathrm{~g} \mathrm{~kg}\right.$ fresh weight $\left.{ }^{-1}\right)$ for DM, N and WSC, respectively. Lobos et al. [83] reported good prediction performance $\left(\mathrm{R}^{2} \geq 0.84\right)$ for fresh grass NIRS analysis for parameters DM $(\mathrm{RMSE}=1.13 \%)$ and CP $(\mathrm{RMSE}=2.22 \%)$, in comparison with low prediction performance $\left(\mathrm{R}^{2} \leq 0.78\right)$ for DMD $(\mathrm{RMSE}=2.41 \%)$, OMD $(\mathrm{RMSE}=2.61 \%)$, and WSC 
(RMSE $=0.06 \%)$ in Chilean permanent pasture. A summary of the accuracy of relevant NIRS calibrations for grass quality is presented in Table 2. A more recent study by Murphy et al. [84] presented NIRS calibrations that could predict DM with a high degree of accuracy $\left(R^{2}=0.86, S E=9.46 \mathrm{~g} \mathrm{~kg}^{-1}\right)$ and $\mathrm{CP}$ with moderate accuracy $\left(\mathrm{R}^{2}=0.84, \mathrm{SE}=20.38 \mathrm{~g} \mathrm{~kg}^{-1}\right)$ in Irish PRG swards. The development of rapid NIRS calibrations to predict fresh grass quality would significantly reduce laboratory labour, inputs, and cost. Furthermore, fresh grass NIRS would enable more precise grassland and feed management decisions to be made on a daily basis.

Table 2. Summary of NIRS grass quality studies and calibration statistics relevant to temperate grassland presented in Murphy et al. [84].

\begin{tabular}{|c|c|c|c|c|c|c|c|c|}
\hline Study & Analyte & Region & Species & Parameters & $\begin{array}{c}\text { Sample } \\
\text { No. }\end{array}$ & $\mathbf{R}^{2}$ & $\begin{array}{c}\text { Error }(\mathrm{g} \\
\left.\mathrm{kg}^{-1}\right)\end{array}$ & RPD \\
\hline $\begin{array}{l}\text { Murphy et al. } \\
\text { (2021) }\end{array}$ & Fresh grass & Ireland & PRG & $\mathrm{DM}, \mathrm{CP}$ & 1812 & $0.85,0.84$ & $9.5,20.4$ & $2.57,2.37$ \\
\hline $\begin{array}{l}\text { Lobos et al. } \\
\text { (2019) }\end{array}$ & Fresh grass & Chile & $\begin{array}{l}\text { Permanent } \\
\text { pasture }\end{array}$ & $\mathrm{DM}, \mathrm{CP}$ & 915 & $0.93,0.84$ & $11.3,22.2$ & $3.7,2.5$ \\
\hline $\begin{array}{l}\text { Parrini et al. } \\
\quad(2019)\end{array}$ & Fresh grass & Italy & $\begin{array}{l}\text { Natural } \\
\text { pasture }\end{array}$ & $\mathrm{DM}, \mathrm{CP}$ & 100 & $0.87,0.88$ & $2.75,2.14$ & $2.75,2.26$ \\
\hline $\begin{array}{c}\text { Bonnal et al. } \\
\text { (2013) }\end{array}$ & Fresh grass & France & $\begin{array}{l}\text { Mixed } \\
\text { swards }\end{array}$ & $\mathrm{CP}$ & 103 & 0.93 & 1.55 & 1.97 \\
\hline $\begin{array}{c}\text { Alomar et al. } \\
(2009)\end{array}$ & Fresh grass & Chile & $\begin{array}{l}\text { Mixed } \\
\text { swards }\end{array}$ & $\mathrm{DM}, \mathrm{CP}$ & 107 & $0.99,0.91$ & $6.55,18.4$ & $7.15,3.69$ \\
\hline $\begin{array}{l}\text { McClure et al. } \\
\quad(2002)\end{array}$ & Fresh grass & USA & Fescue & $\mathrm{N}$ & 31 & 0.88 & 6 & - \\
\hline $\begin{array}{c}\text { Park et al. } \\
(1998)\end{array}$ & Fresh grass silage & Ireland & - & $\mathrm{DM}, \mathrm{N}$ & 136 & $0.85,0.78$ & $23.3,28.1$ &,- 4.8 \\
\hline $\begin{array}{l}\text { Burns et al. } \\
\text { (2014) }\end{array}$ & $\begin{array}{c}\text { Dried \& milled } \\
\text { grass }\end{array}$ & Ireland & PRG & $\mathrm{CP}$ & 2076 & 0.98 & 5.1 & - \\
\hline $\begin{array}{c}\text { Jafari et al. } \\
(2003)\end{array}$ & $\begin{array}{l}\text { Dried \& milled } \\
\text { grass }\end{array}$ & Ireland & PRG & $\mathrm{CP}$ & 153 & 0.96 & 6.8 & - \\
\hline
\end{tabular}

PRG = perennial rye grass, $\mathrm{DM}=$ dry matter, $\mathrm{CP}=$ crude protein $\left(\mathrm{g} \mathrm{kg} \mathrm{kg}^{-1} \mathrm{DM}\right), \mathrm{N}=$ nitrogen, $\mathrm{R}^{2}=$ coefficient of determination, Error $=$ standard error of cross-validation, standard error of prediction or root mean squared error depending on study, RPD = ratio of percent deviation, '-' = denotes where data was not published as part of study.

In the past two decades, NIRS technological developments in the area of diode array spectrometers and micro-electric-mechanical-systems (MEMS) have allowed new possibilities regarding real-time in-situ NIRS analysis of fresh grass [85,86]. Portable spectrometers have numerous advantages over lab-based systems including, in-situ measurement, lower costs, real-time results and non-destructive sampling. Portable NIRS has noted limitations regarding light noise, particle size, wavelength range and moisture effects [86]. A high speed and durable portable spectrometer has been developed for the selection of grass species for breeding purposes [87]. This NIRS sensor was capable of predicting DM of fresh grass, with an acceptable correlation in relation to wet chemistry analysis $\left(R^{2}=0.73\right)$, in real-time and was built into a grass plot harvester. Mendarte et al. [88] outlined the potential for using portable NIRS to determine the quality of standing mountain pasture in the Basque Country, reporting reasonable prediction results for $\mathrm{DM}\left(\mathrm{R}^{2}=0.82\right.$, SECV $\left.=0.56 \mathrm{~g} \mathrm{~kg}^{-1}\right)(\mathrm{SECV}=$ standard error of cross validation $)$ and $\mathrm{CP}\left(\mathrm{R}^{2}=0.62, \mathrm{SECV}=\right.$ $1.50 \mathrm{~g} \mathrm{~kg}^{-1} \mathrm{DM}$ ) in relation to laboratory reference analysis. Reddersen et al. [79] assessed the use of portable NIRS to evaluate the feed quality of mixed species standing swards in Germany and concluded that it was only capable of predicting approximate values $\left(R^{2}=\right.$ $0.72, \mathrm{SECV}=3.9 \mathrm{~g} \mathrm{~kg}^{-1} \mathrm{DM}$ ) of $\mathrm{N}$ content, due to the high presence of moisture and low levels of sample homogeneity. Smith et al. [89] used a similar technology in an Australian 
PRG breeding programme and recommended that portable NIRS was feasible as a high speed and low cost method of evaluating nutritive value for parameters CP, DM, DMD, WSC, acid detergent fibre, and neutral detergent fibre, reporting $\mathrm{R}^{2}$ values ranging between 0.49 and 0.89 and RMSE values between $1.84 \%$ and $3.41 \%$.

An issue that constrains the development of portable NIRS applications is that many portable spectrometers on the market are 'closed box' systems and researchers do not have access to the calibration data within them [86]. In recent years, an on-line NIRS device for silage and pasture quality assessment has been developed in the UK (NIR4) (Figure 3). The NIR4 is capable of scanning fresh pre-cut grass and uploading the spectral data to the user's handheld smart device for rapid analysis, with calibrations for parameters DM, CP, WSC and DMD [90]. However, no published data on the precision of this system could be found in the literature. A study by Patton et al. [91] assessed the efficacy of three portable NIRS sensors from different manufacturers to analyse quality traits of PRG swards in the North of Ireland. They concluded that any of the instruments tested could not replicate quality predictions made from a lab based NIRS spectrometer. Hart et al. [92] reported high levels of systemic error (9-22\%) using portable NIRS on Swiss mixed swards. There is considerable scope for portable NIRS applications in grassland farming. More research needs to be performed on environmental, moisture, and sample particle heterogeneity effects to establish the feasibility of portable NIRS.

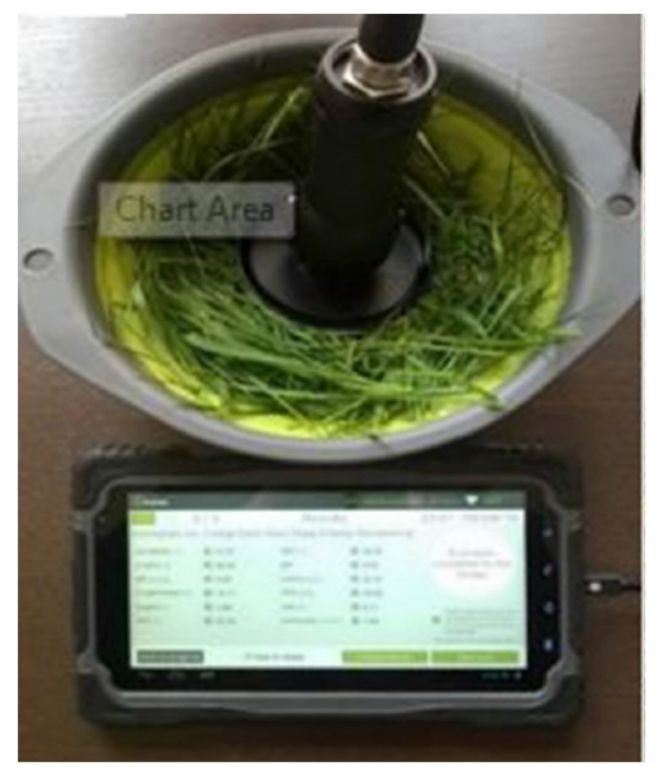

Figure 3. Image of NIR4 grass quality analysis system reprinted from ref. [90].

\section{Terrestrial Sensing}

In the context of this review, terrestrial sensing refers to non-spectral sensors that interact with the sward at (or close to) ground level.

Terrestrial on-the-go soil electrode sensing has been used by Vogel et al. [93] to investigate potential relationships between soil $\mathrm{PH}$, moisture content, and the spatial variation of herbage mass on grazed German pasture. The study utilised a tractor mounted Veris mobile sensor platform (Figure 4) for rapid soil analysis and apparent soil electrical conductivity was measured to predict soil moisture content. 


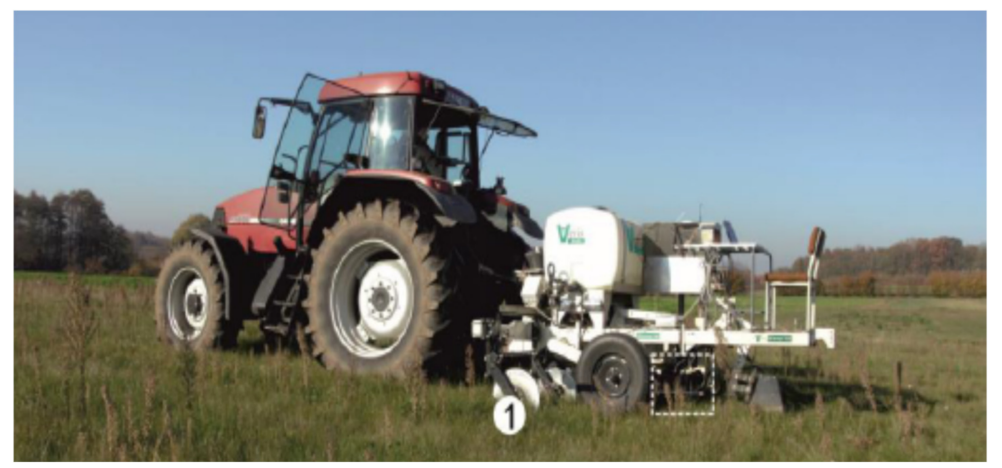

Figure 4. Tractor mounted Veris mobile sensor platform reprinted from ref. [93] for on-the-go soil analysis on grazed pasture.

The use of a sensor to directly measure sward height using ultrasonic waves has been investigated on mixed species German swards by Reddersen et al. [94], who found that it predicted HM with reasonable accuracy $\left(\mathrm{R}^{2}=0.73-0.76\right.$, RMSECV $\left.=0.88-1.17 \mathrm{t} \mathrm{DM} \mathrm{ha}{ }^{-1}\right)$ (RMSECV = root mean squared error of cross-validation). The study further found that combining ultrasonic sward height (USH) and remote sensing data in a multi-sensor (leaf area index and hyperspectral sensors) approach increased HM prediction accuracy by $30 \%$. An earlier study by Fricke et al. [95] investigated combining USH with GPS on a vehicle for real-time 'on the go' measurement and rapid yield mapping of pasture, as seen in Figure 5a. A number of USH measurement limitations were highlighted in that study, including poor precision caused by the wide ultrasonic response area and poor responses to changes in sward geometry and heterogeneity. The study further outlined the potential for combining arrays of low cost USH sensors, which could be fitted onto tractors or mowers to generate cheap and minimal effort HM predictions. Safari et al. [96] compared the use of mobile USH and spectral sensing (Figure 5b) with static sensing, reporting lower prediction accuracy for mobile measurement due to positional errors caused by variation in the ground profile. Moeckel et al. [97] found poor results $\left(\mathrm{R}^{2}=\right.$ $0.36-0.74, \mathrm{SE}=675-1118 \mathrm{~kg} \mathrm{DM} \mathrm{ha}^{-1}$ ) for predicting HM using USH on mixed species swards, reporting high errors in mature swards as a result of patches of rejected grass left after grazing. The study further investigated the potential for combining spectral data from spectrometers and satellites with USH and found that utilising both visible and NIR spectral data improved HM prediction performance $\left(R^{2}=0.66-0.88\right.$, SE $\left.=485-866 \mathrm{~kg} \mathrm{DM} \mathrm{ha}^{-1}\right)$. A similar USH measurement system that could be fixed to a farm vehicle to measure pasture height while traveling at speeds of $20 \mathrm{~km} \mathrm{~h}^{-1}$ achieved HM prediction accuracies of $\mathrm{R}^{2}=0.75$ and $\mathrm{SE}=270-350 \mathrm{~kg} \mathrm{ha}^{-1}$ on New Zealand grassland [98]. Apparent advantages of USH sensing for grass measurement are that it is relatively fast, low cost, and simple to implement, with the potential for mobile application. Conversely, limitations exist with regard to the precision of USH as a result of high variation in signal responses to canopy heterogeneity.

The C-DAX Pasturemeter is a terrestrial sensing device for predicting HM that has been developed and is in common use in New Zealand. The C-DAX is mounted on wheels and is designed to be towed behind a quad bike at approximate speeds of $20 \mathrm{~km} / \mathrm{h}$, as illustrated in Figure 6. This device measures pasture height using light emitting and sensing photodiode arrays. As the C-DAX is towed through the pasture the photodiode sensors record a height profile of the pasture. Studies have concluded that measuring pasture standing height has notable limitations with regard to predicting HM in comparison with the RPM [26,27]. Despite this, the C-DAX has one significant advantage over the RPM. The C-DAX is capable of acquiring much more data (200 measurements per second) in a more rapid manner than the RPM without the need of walking [99,100]. King et al. [101] compared the measurement accuracies of the C-DAX and RPM over a range of pastures in New Zealand throughout a single grazing season. Results in terms of RMSE ranged between 576 and $655 \mathrm{~kg} \mathrm{DM} \mathrm{ha}^{-1}$ for the C-DAX and 441 and $552 \mathrm{~kg} \mathrm{DM} \mathrm{ha}^{-1}$ for the 
RPM. Oudshoorn et al. [102] discovered that the C-DAX predicted HM to within acceptable accuracy $\left(R^{2}=0.76\right)$ on Danish PRG/WC swards. The prediction error calculated by Schori [103] was slightly higher for the C-DAX $\left(\mathrm{SE}=311 \mathrm{~kg} \mathrm{DM} \mathrm{ha}^{-1}\right)$ compared with the RPM ( $\mathrm{SE}=285 \mathrm{~kg} \mathrm{DM} \mathrm{ha}^{-1}$ ), on Swiss mixed swards over three grazing seasons. The C-DAX also has in-built GPS geo-tagging capabilities, which have been utilised to generate yield maps for targeted pasture management applications [104]. Currently, the C-DAX is not commonly used by Irish grassland farmers. This may be due to a perception that predicting HM by measuring standing sward height is not as accurate as CSH because it is not as sensitive to sward density, as outlined by Shalloo et al. [24].

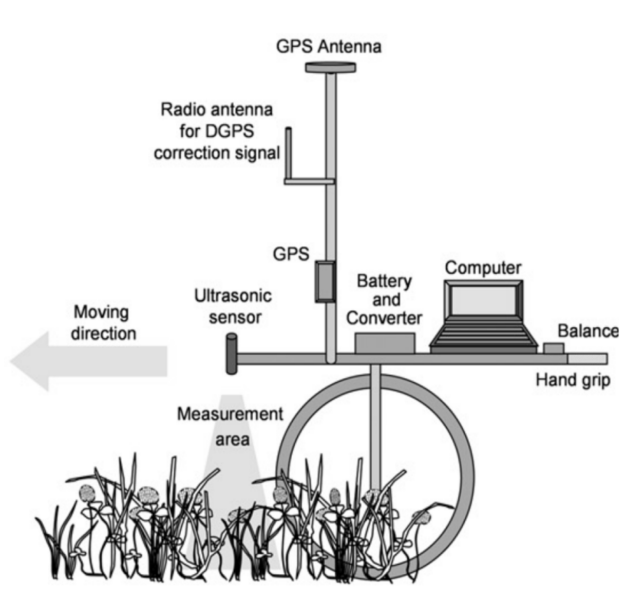

(a)

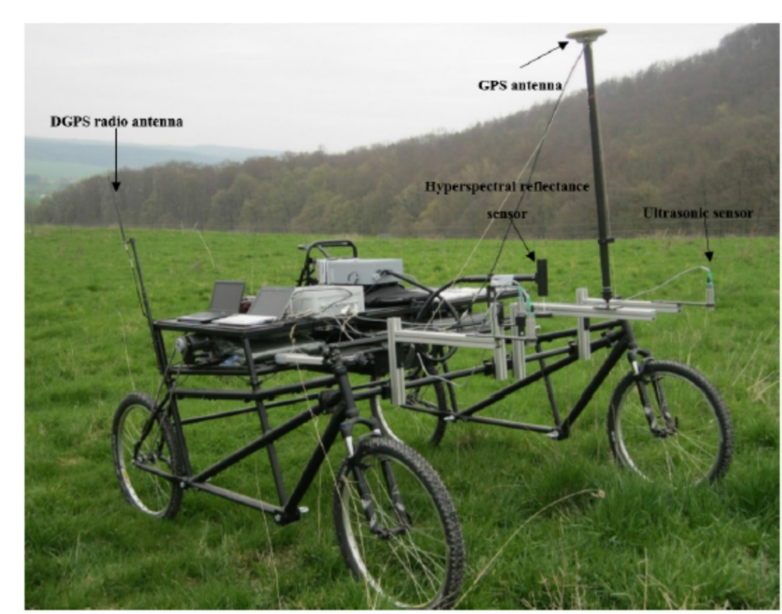

(b)

Figure 5. (a) Schematic of 'on the go' grass measurement system presented in Fricke et al., reprinted with permission from ref. [95]. Copyright 2021 Elsevierand (b) image of similar system reprinted from ref. [96].

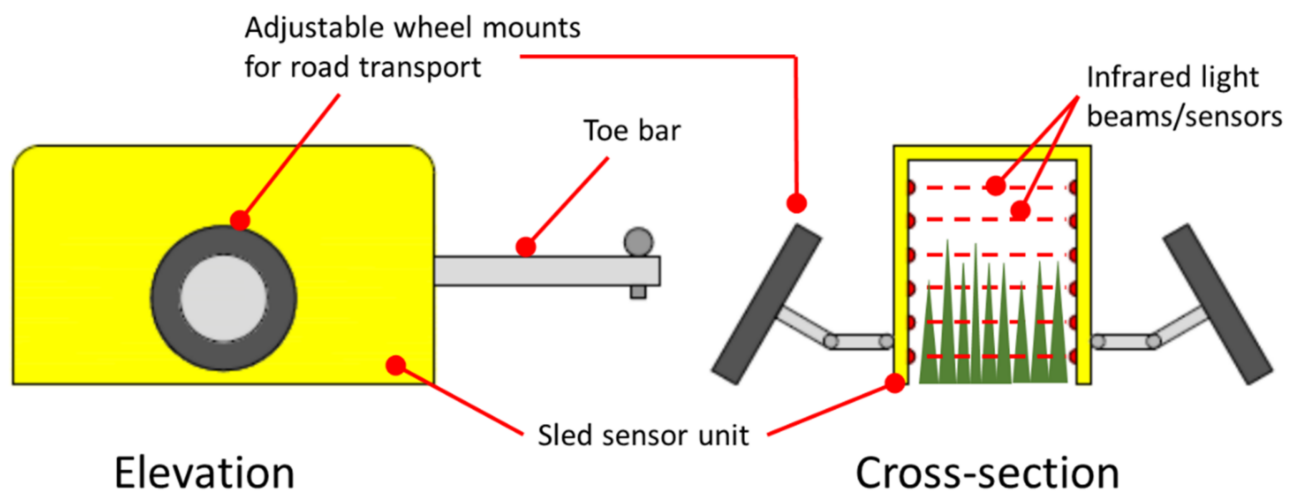

Figure 6. Elevation and cross section schematic of the C-DAX Pasturemeter.

Terrestrial sensing of pasture may enable grass measurement to be conducted by autonomous ground vehicles (AGV), which work within close proximity to the ground in a remote manner. Research into these vehicles for PA applications has predominantly been focused on the arable sector. A more recent novel modification of the C-DAX is a proposed pasture robot currently under development in New Zealand [105]. The concept combines an AGV with the C-DAX system. The robot is designed to autonomously navigate from a central charging station to a paddock and traverse the pasture using a pre-programmed sampling strategy, negating the need for physical labour. The entire area of a 2-ha paddock could be sampled for field mapping purposes within $5 \mathrm{~h}$, or a representative area of the same paddock could be sampled for basic grassland management purposes in under $30 \mathrm{~min}$. Potential for fitting soil sampling and grass quality sensors to this system is also being considered. Gobor et al. [106] proposed a similar pasture robot system for use on 
German pastures. Their concept incorporates a mulcher system on the robotic platform (Figure 7) so that areas of rejected pasture, identified by a sward height sensor on the robot, can be mulched to encourage the regrowth of high-quality pasture. Likewise, areas of poor $\mathrm{HM}$ could be treated with a seeder incorporated on the proposed robotic rover platform. Sampling protocol design would need to be a significant consideration with regard to the potential use of AGVs for pasture measurement. The design of optimum AGV sampling protocols for pasture measurement would need to be in line with best practice for pasture sampling. A significant advantage of an AGV system would be that measurement labour and time do not place the same level of constraint on protocol design. Conversely, when compared with unmanned aerial vehicle (UAV)-based remote sensing, AGV systems have a number of disadvantages, including slower data collection, damage to sward caused by movement paths, and higher cost. Theses disadvantages may be offset by the higher resolution of measurement data and reduced climate noise interference that is achievable using AGVs when compared with remote sensing $[107,108]$.

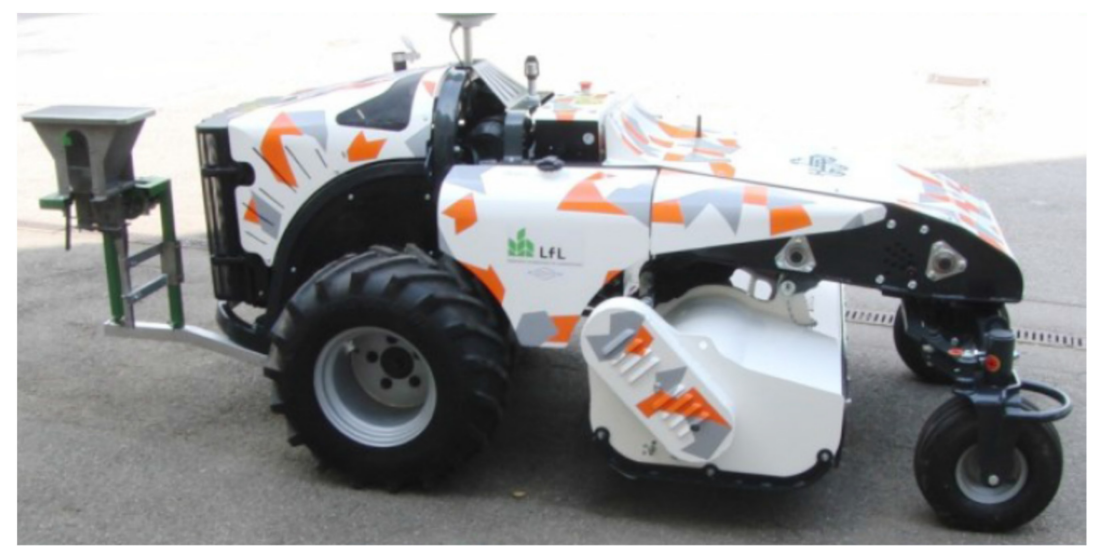

Figure 7. Pasture robot system concept proposed by Gobor et al. [108] incorporating mulcher and seeder.

\section{Proximal Spectral Sensing}

In the context of this review, proximal spectral sensors refer to spectral sensors that operate within $2 \mathrm{~m}$ of the soil surface, as defined by Viscarra Rossel et al. [109]. Proximal spectral sensing includes the previously discussed portable NIRS technologies, but the following section deals with all other prevalent proximal spectral sensing technologies.

Hyperspectral sensing (HS) has the ability to capture a wide range of spectral data, ranging from the visible to NIR light regions, which results in greater availability of data for prediction modelling in comparison with NIRS. Devices for HS can be handheld for manual proximal sensing or mounted on un-manned aerial vehicles and satellites. Disadvantages of HS include the capture of a large amount of data that is redundant for modelling and the high cost of instrumentation [94]. Similar to NIRS, HS data can be used to model pasture quantity and quality using chemometric modelling techniques. Pullanagari et al. [110] used a HS canopy probe sensor $(500-2400 \mathrm{~nm}$ ) to predict a range of in-situ standing sward quality characteristics on PRG/WC dominant swards in New Zealand. The study achieved satisfactory prediction results for $\mathrm{CP}\left(\mathrm{R}^{2}=0.78, \mathrm{RMSE}=2.33 \% \mathrm{DM}\right), \mathrm{ME}\left(\mathrm{R}^{2}=0.83, \mathrm{RMSE}=\right.$ $\left.0.46 \mathrm{MJ} \mathrm{kg}^{-1}\right)$, and OMD $\left(\mathrm{R}^{2}=0.83, \mathrm{RMSE}=4.02 \% \mathrm{DM}\right)$. The samples used were not spread across an entire growing season and reference analysis was conducted by lab based NIRS.

Hyperspectral sensing enables the prediction of sward characteristics by more basic means of spectral modelling referred to as vegetation indices (VI), which are commonly used for remote sensing applications. One of the most used VI is the normalised deference vegetation index (NDVI), which estimates the quantity of vegetation present by the ratio of red and NIR light wavelengths that are absorbed by pasture photosynthesis [24]. Another commonly researched VI is the leaf area index (LAI), which is a measure of the sward foliage area against ground area [94]. Reddersen et al. [94] found poor results for HS prediction 
of HM using LAI $\left(\mathrm{R}^{2}=0.36-0.44\right.$, $\left.\mathrm{SE}=1.5-1.8 \mathrm{t} \mathrm{DM} \mathrm{ha}{ }^{-1}\right)$ using the HS configuration illustrated in Figure 8. The study further investigated the use of HS imagery $(350-2500 \mathrm{~nm})$ to predict HM by means of chemometric modelling with more positive results $\left(R^{2}=0.70\right.$ $0.89, \mathrm{SE}=0.66-0.85 \mathrm{t} \mathrm{DM} \mathrm{ha}^{-1}$ ). Moeckel et al. [97] discovered that normalized difference spectral index (NDSI) in combination with USH significantly improved HM prediction $\left(R^{2}=0.52, S E=1000 \mathrm{~kg} \mathrm{DM} \mathrm{ha}^{-1}\right)$. Results for HS (305-1700 nm) prediction of HM were poor $\left(\mathrm{R}^{2}=0.48, \mathrm{SE}=950 \mathrm{~kg} \mathrm{DM} \mathrm{ha}^{-1}\right)$ and limitations in HS caused by the high presence of senescent material in the sward were observed later in the growing season. AncinMurguzur et al. [111] found a significant correlation between HS and HM on Norwegian mixed species swards $\left(R^{2}>0.55\right.$, RMSE $\left.\leq 180 \mathrm{~g} \mathrm{~m}^{-2}\right)$, but noted increased error due to environmental influences on spectral signatures observed in cloudy and wet conditions. The study further showed that spectral data captured in the range of $350-900 \mathrm{~nm}$ was more robust against the influences of moisture. Pullanagari et al. [112] found strong correlations for $C P\left(R^{2}=0.65-0.83\right)$ on dairy pasture in New Zealand using HS. Askari et al. [113] found positive results for predicting $\mathrm{HM}\left(\mathrm{R}^{2}=0.88\right.$, RMSE $\left.=160 \mathrm{~kg} \mathrm{DM} \mathrm{ha}^{-1}\right)$ and $\mathrm{CP}\left(\mathrm{R}^{2}=0.82\right.$, RMSE $=10.0 \mathrm{~g} \mathrm{~kg} \mathrm{DM}^{-1}$ ) using a handheld HS camera on Irish PRG swards over two growing seasons.

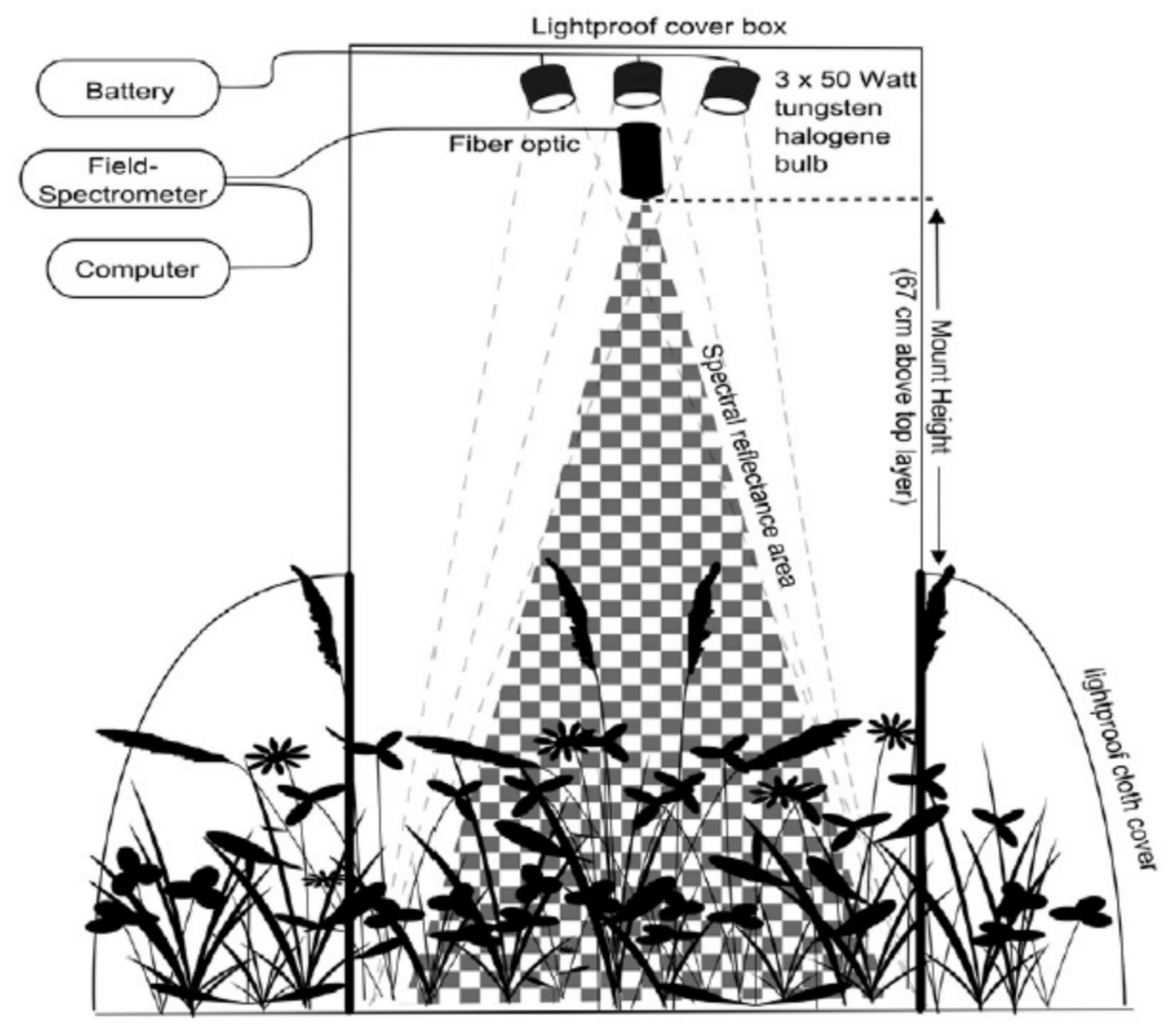

Figure 8. Schematic of hyperspectral sensing measurement system reprinted with permission from ref. [94].Copyright 2021 Elsevier.

There are evident advantages to HS including non-destructive sampling, large sample area coverage, spatial variation identification and potential incorporation with autonomous vehicles or tractor mounts. One of the main barriers to this technology is the high cost of HS devices, although this may decrease in the near future. Furthermore, HS and all other proximal spectral sensing technologies also have sampling issues with regard to accounting for spatial heterogeneity within swards. 


\section{Remote Sensing}

Remote sensing refers to all sensing techniques that operate at a distance greater than two meters from ground level [109]. This includes sensing methodologies that use UAVs, manned aircraft, and satellites. In the past decade, research on remote sensing methods for predicting grass yield and quality has increased. Remote sensing has the potential to cover larger sampling areas with minimal labour requirements. A range of remote sensing technologies can be fixed to UAVs, which can fly at low altitudes to obtain spectral data at high resolutions. Rueda-Ayala et al. [108] found weak correlations $\left(R^{2}<0.6\right)$ between red, green, blue (RGB) wavelength sensing data and HM on PRG dominant Norwegian swards and reported difficulties in measurement precision due to environmental factors such as wind speed, sunlight and cloud cover. Conversely, that study found that UAV sensing was less variable than terrestrial sensing data. Askari et al. [113] determined that red and green wavelength bands were important for predicting $\mathrm{CP}$ by means of UAV sensing on Irish PRG swards. Capolupo et al. [114] showed that UAV HS could predict sward height $\left(\mathrm{R}^{2}=\right.$ 0.70-0.86, RMSE $=2.13-2.29 \mathrm{~cm}), \mathrm{HM}\left(\mathrm{R}^{2}=0.36-0.83, \mathrm{RMSE}=2.95-3.81 \mathrm{~kg} \mathrm{DM} \mathrm{plot}^{-1}\right)$, and $C P\left(R^{2}=0.56-0.76\right.$, RMSE $\left.=11.73-12.28 \mathrm{~g} \mathrm{~kg}^{-1} \mathrm{DM}\right)$ on German controlled trial plots.

Multi-spectral (MS) sensors that emit light radiation in discrete spectral bands and at broader resolutions than HS have been more commonly deployed in UAV research for pasture analysis. One major advantage of MS devices is that they are typically cheaper than HS instruments. Pullanagari et al. [115] reported reasonable precision $\left(R^{2}=0.6,0.66\right.$, 0.68 ; RMSE $=2.88 \%, 065 \%, 5.27 \%$ ) for parameters $C P, M E$, and OMD on New Zealand PRG dominant pastures over two grazing seasons using a proximal MS sensor, spanning 16 discrete wavelengths $(460-1680 \mathrm{~nm})$. A prominent issue with MS sensing was further highlighted in the study. Many MS sensors depend on natural light to illuminate the sward. Consequently, low atmospheric light intensity can cause sampling problems. Askari et al. [113] reported good prediction results for $H M\left(R^{2}=0.78, R M S E=215 \mathrm{~kg} \mathrm{DM} \mathrm{ha}^{-1}\right)$ and CP $\left(\mathrm{R}^{2}=0.77\right.$, RMSE $\left.=13.6 \mathrm{~g} \mathrm{~kg} \mathrm{DM}^{-1}\right)$ using UAV MS (Figure 9) on Irish PRG pastures over two grazing seasons. Togeiro de Alckmin et al. [58] reported that MS $\left(R^{2}=0.79\right.$, RMSE $=405.8 \mathrm{~kg} \mathrm{DM} \mathrm{ha}^{-1}$ ) had a $116 \mathrm{~kg} \mathrm{DM} \mathrm{ha}^{-1}$ lower RMSE compared with the RPM for HM prediction, when an optimal selection of VI was used. Oliveira et al. [116] showed that a combination of HS sensing and 3D imagery out-performed MS measurements on Finish swards, accurately predicting silage sward HM $(\mathrm{RPE}=14.6 \%)$, digestibility $(\mathrm{RPE}=1.9 \%)$, and $\mathrm{N}$ content $(\mathrm{RPE}=13.6 \%)$.

A number of similar limitations have been reported for both proximal and aerial spectral sensing of pasture. The most significant limitation is the heterogeneity of grassland, which is much greater than tillage, where remote spectral sensing has become more established. The temporal change in the ratio of photosynthetically to non-photosynthetically active (vegetative vs. dead) material in grassland swards has significant effects on spectral absorption. Achieving adequate levels of spatial resolution to distinguish significant variations in pasture performance for targeted management purposes is also an issue with pasture sensing. Sensors with sufficient spatial and sensing resolution to identify pasture variation can be very expensive. Similar to NIRS, high moisture content within standing swards can obscure spectral features of certain quality parameters [112].

Light detection and ranging (LiDAR) is another potential technology that could be used in conjunction with UAVs for remote sensing of pasture. This technology utilises light beams (visible/infrared) emitted at a high irradiance rate to measure the distance and shape of terrestrial objects. The time it takes for each emitted light beam to be reflected back to the LiDAR sensor receiver is used to develop a point cloud dataset for each target object. Obanawa et al. [117] reported an average absolute error of $12 \mathrm{~mm}( \pm 10 \mathrm{~mm})\left(R^{2}=\right.$ 0.93 ) at a $20 \mathrm{~mm}$ resolution for LiDAR prediction of grass height on Italian ryegrass pasture in Japan. Disadvantages of LiDAR include its relatively high cost and susceptibility to high measurement error in windy conditions $[118,119]$. Moreover, the use of grass height to predict HM has further limitations as previously discussed. 


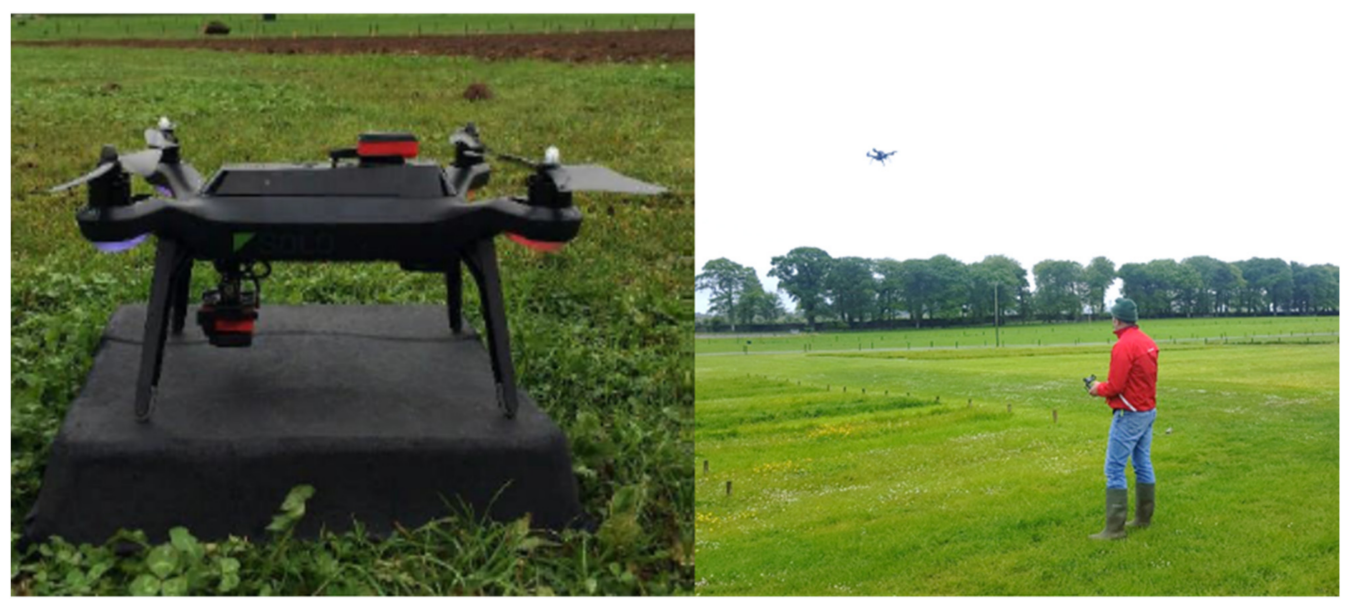

(a)

(b)

Figure 9. (a) UAV with multispectral sensor and (b) UAV plot sensing fly over from study by Askari et al. [113].

Several studies have investigated the potential of utilising satellite-based MS and HS to predict pasture quantity and quality $[111,113,120]$. The distinct advantages of satellite sensing relate to the larger spatial coverage, in terms of data acquisition, that can be achieved. The European Space Agency's Sentinel-2 project comprises of two orbital satellites loaded with MS technology capable of monitoring land use variations at $10 \mathrm{~m}, 20 \mathrm{~m}$, and $60 \mathrm{~m}$ resolutions [121]. Sibanda et al. [120] outlined how Sentinel-2 MS data could be used to predict HM with comparable accuracy to proximal HS on South African experimental grassland plots $\left(27-250 \mathrm{~m}^{2}\right)\left(\mathrm{R}^{2}=0.58\right.$, RMSE $\left.=67.9 \mathrm{~kg} \mathrm{ha}^{-1}\right)$. Askari et al. [113] reported moderate success for predicting $\mathrm{HM}\left(\mathrm{R}^{2}=0.82, \mathrm{RMSE}=600 \mathrm{~kg} \mathrm{DM} \mathrm{ha}^{-1}\right)$ and poor results for CP $\left(\mathrm{R}^{2}=0.62\right.$, RMSE $\left.=13.3 \mathrm{~g} \mathrm{~kg}^{-1} \mathrm{DM}\right)$ using Sentinel-2 data on Irish grassland plots $\left(7.5 \mathrm{~m}^{2}\right)$ and grazed paddocks ( $\geq 1 \mathrm{ha}$ ). The study illustrated that the overriding limitation for satellite spectral sensing on Irish pasture is frequent cloud cover, as data acquisition was not possible on days with over $30 \%$ cloud cover.

An alternative technology for satellite remote sensing of pasture that may overcome cloud cover and illumination limitations is synthetic aperture radar (SAR), which uses high resolution radio wave reflectance to predict pasture height. Barrett et al. [122] utilized SAR to overcome cloud cover limitations for satellite classification of Irish grasslands. A more recent study that used SAR on Irish PRG dominant dairy pasture ( $\geq 1$ ha) yielded promising results for both sward height $\left(R^{2}=0.55\right)$ and $H M\left(R^{2}=0.75\right)[123]$ at a $25 \mathrm{~cm}$ spatial resolution. However, research into this technology is still at an early stage.

In light of the research outlined for terrestrial, proximal, and aerial sensing techniques, it is evident that longer, more detailed studies over numerous seasons and sward types need to be conducted before these technologies can become established within pasture-based agriculture. Results from the most recent research findings discussed in this review, which were most relevant to the measurement of temperate grasslands used for pasture-based livestock production (PRG/WC Irish pasture), are summarised in Table 3. 
Table 3. Summary of grass measurement systems from the research discussed in this review that were most relevant to temperate (Irish) grasslands.

\begin{tabular}{|c|c|c|c|c|c|c|c|c|c|c|c|}
\hline System & $\begin{array}{l}\text { Relevant } \\
\text { Studies }\end{array}$ & Region & Measure & Prediction & $\begin{array}{l}\text { Sample } \\
\text { No. }\end{array}$ & \multicolumn{2}{|c|}{ Herbage Quantity } & \multicolumn{2}{|c|}{ Herbage Quality } & Advantage & Disadvantage \\
\hline \multicolumn{12}{|c|}{ Conventional systems } \\
\hline & & & & & & $\mathrm{R}^{2}$ & $\begin{array}{l}\text { Error (kg DM } \\
\left.\mathrm{ha}^{-1}{ }^{\mathrm{a}} \mathrm{mm}^{\mathrm{b}}\right)\end{array}$ & $\mathrm{R}^{2}$ & $\begin{array}{c}\text { Error }\left(\mathrm{g} \mathrm{kg}^{\mathrm{c}}, \mathrm{g}\right. \\
\mathrm{kg} \mathrm{DM}^{-1 \mathrm{~d}}, \% \mathrm{e}^{\mathrm{e}} \\
\left.\% \mathrm{DM}^{\mathrm{f}}\right)\end{array}$ & & \\
\hline Rising plate meter & $\begin{array}{l}\text { Murphy et al. } \\
\text { [59] }\end{array}$ & Ireland & $\begin{array}{l}\text { Compressed } \\
\text { sward height }\end{array}$ & $\mathrm{HM}$ & 1977 & 0.77 & $354^{a, *}$ & - & - & $\begin{array}{l}\text { Rapid, usability, } \\
\text { cost }\end{array}$ & $\begin{array}{c}\text { Labour intensive, } \\
\text { accuracy }\end{array}$ \\
\hline Visual assessment & $\begin{array}{c}\mathrm{O}^{\prime} \text { Donovan et al. } \\
{[26]}\end{array}$ & Ireland & $\begin{array}{c}\text { Perceived } \\
\text { herbage cover }\end{array}$ & $\mathrm{HM}$ & 2205 & 0.95 & $193^{a, f}$ & - & - & Minimal labour & High subjectivity \\
\hline NIRS & $\begin{array}{l}\text { Murphy et al. } \\
{[84]}\end{array}$ & Ireland & $\begin{array}{c}\text { Spectral } \\
\text { absorption }\end{array}$ & $\mathrm{DM}, \mathrm{CP}$ & 1812 & - & - & $0.86,0.84$ & $9.46^{c}, 20.38^{d, t}$ & Accuracy & $\begin{array}{c}\text { High cost, lab } \\
\text { based, destructive }\end{array}$ \\
\hline \multicolumn{12}{|c|}{ State of the art } \\
\hline $\begin{array}{l}\text { Light sensing } \\
\text { (C-DAX) }\end{array}$ & Schori [103] & Switzerland & $\begin{array}{c}\text { Sward surface } \\
\text { height }\end{array}$ & $\mathrm{HM}$ & 439 & 0.77 & $311^{\mathrm{a}, \mathrm{f}}$ & - & - & Rapid, automation & Accuracy \\
\hline LiDAR & $\begin{array}{c}\text { Obanawa et al. } \\
\text { [117] }\end{array}$ & Japan & $\begin{array}{c}\text { Sward surface } \\
\text { height }\end{array}$ & $\mathrm{SSH}$ & 25 & 0.93 & $12^{b, * *}$ & - & - & Remote sensing & $\begin{array}{l}\text { High cost, wind } \\
\text { error, accuracy }\end{array}$ \\
\hline Ultrasonic & $\begin{array}{c}\text { Reddersen et al. } \\
\text { [94] }\end{array}$ & Germany & $\begin{array}{c}\text { Sward surface } \\
\text { height }\end{array}$ & $\mathrm{HM}$ & 167 & 0.76 & $880^{\mathrm{a}, *}$ & - & - & Rapid, automation & Accuracy \\
\hline Portable NIRS & Smith et al. [89] & $\begin{array}{c}\text { Victoria, } \\
\text { Aus- } \\
\text { tralia }\end{array}$ & $\begin{array}{c}\text { Spectral } \\
\text { absorption }\end{array}$ & $\begin{array}{c}\text { DM, DMD, WSC } \\
\text { CP }\end{array}$ & 540 & - & - & $\begin{array}{c}0.69 \\
0.82,0.49,0.74\end{array}$ & $\begin{array}{c}3.14^{\mathrm{e}}, 2.70,2.77 \\
2.02^{\mathrm{f}, *}\end{array}$ & $\begin{array}{l}\text { In-situ quality } \\
\text { analysis }\end{array}$ & Accuracy \\
\hline $\begin{array}{l}\text { Hyperspectral } \\
\text { sensing }\end{array}$ & $\begin{array}{l}\text { Askari et al. } \\
\text { [113] }\end{array}$ & Ireland & $\begin{array}{c}\text { Spectral } \\
\text { absorption }\end{array}$ & $\mathrm{HM}, \mathrm{CP}$ & 84 & 0.88 & $160^{a, *}$ & 0.82 & $10^{\mathrm{d}, *}$ & $\begin{array}{l}\text { Remote sensing, } \\
\text { accuracy }\end{array}$ & High cost \\
\hline $\begin{array}{l}\text { Multispectral } \\
\text { sensing }\end{array}$ & $\begin{array}{c}\text { Askari et al. } \\
\text { [113] }\end{array}$ & Ireland & $\begin{array}{c}\text { Spectral } \\
\text { absorption }\end{array}$ & $\mathrm{HM}, \mathrm{CP}$ & 126 & 0.78 & $215^{\mathrm{a}, *}$ & 0.77 & $13.6^{\mathrm{d}, *}$ & $\begin{array}{l}\text { Remote sensing, } \\
\text { cost }\end{array}$ & $\begin{array}{l}\text { Lack of long term } \\
\text { studies }\end{array}$ \\
\hline $\begin{array}{c}\text { Satellite } \\
\text { multispectral }\end{array}$ & $\begin{array}{l}\text { Askari et al. } \\
\text { [113] }\end{array}$ & Ireland & $\begin{array}{c}\text { Spectral } \\
\text { absorption }\end{array}$ & $\mathrm{HM}, \mathrm{CP}$ & 176 & 0.82 & $600^{a, *}$ & 0.62 & $13.3^{d, *}$ & Remote sensing & $\begin{array}{l}\text { Cloud cover, } \\
\text { accuracy }\end{array}$ \\
\hline $\begin{array}{l}\text { Synthetic Aperture } \\
\text { radar }\end{array}$ & Ali et al. [123] & Ireland & $\begin{array}{c}\text { Sward surface } \\
\text { height }\end{array}$ & $\mathrm{HM}$ & 264 & 0.75 & - & - & - & Satellite sensing & Lack of research \\
\hline
\end{tabular}

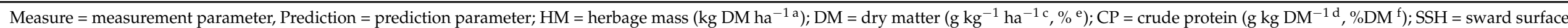

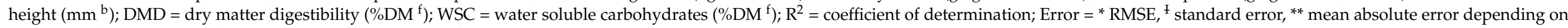
study; ' ${ }^{\prime}=$ denotes where data was not published as part of study. 


\section{Decision Support Systems for Grassland Measurement}

Decision support tools (DST) are becoming more frequently used by grassland farmers to optimise the end use of their grass measurement data for the purposes of herbage allocation and pasture management. A number of grassland management DSTs have been developed in Europe $[124,125]$ and an increasing amount of grassland data is being stored on cloud computing platforms. PastureBase Ireland (PBI) is a DST that assists farmers in determining appropriate actions to be taken to optimise grassland management, mainly by processing uploaded pasture HM cover estimations to determine appropriate herbage allocations in accordance with on-farm growth rates [20]. One significant advantage of DSTs, such as PBI, is that they can perform as national databases for research and innovation. PastureBase can capture data for a range of paddock management parameters from farms across Ireland, which can be used for regional research studies [126]. User collaboration by means of online discussion group portals is also enabled through PBI's interface [24]. Recent data from PBI indicates that farmers using the system are utilising more grass than the Irish national average $\left(8 \mathrm{t} \mathrm{DM}_{\text {year }}{ }^{-1}\right)$ and are growing between 11 and $15 \mathrm{t} \mathrm{DM} \mathrm{year}^{-1}$ [127].

Studies have utilised online DST databases to combine grassland management factors with measurement and meteorological data from local weather stations to forecast HM growth rates [128,129]. Romera et al. [130] utilised an algorithm to continuously train a model to simulate growth factors between measurement dates on New Zealand dairy pastures. These growth factor simulations were based on a combination of meteorological and grass measurement data. Herrmann et al. [131] combined $\mathrm{N}$ fertilization, defoliation frequency, grass species, and daily weather data to predict $\mathrm{HM}$ and $\mathrm{CP}$ on pastures in Germany. In the near future, on-farm sensor technologies could provide data on site-specific meteorological and soil conditions to increase HM prediction accuracy [69].

One limitation of the previously mentioned DSTs is that they are currently only capable of processing HM and sward height data, which are acquired using conventional measurement techniques. Scope for a holistic grass management DST that incorporates state of the art grass technologies, which can measure both pasture quantity and quality, has been identified [132]. GrassQ was a European wide project that aimed to develop a holistic precision grassland measurement and management system, which encompassed both ground based and remote sensing measurement technologies [133]. For new DSTs to be adopted for regular use by grassland farmers, they will need to ensure reduction in labour and return of investment. The GMOT, a prototype grass measurement optimisation tool developed by Murphy et al. [35], generated grass measurement protocols that were optimised for both precision and labour efficiency. The tool was capable of optimising measurement routes and simulating measurement error, which facilitated cost benefit analysis to be conducted for each measurement protocol based on measured HM vs. estimated labour and error costs. Cost-benefit analysis should be an integral part of the design of any future grass management support system to determine the efficacy of investing in new measurement technologies at farm level [24].

\section{Current Challenges Relating to Precision Pasture Measurement}

Significant challenges currently restricting the implementation of precision pasture measurement at farm level that have been highlighted in the reviewed literature include sward heterogeneity, labour, and perceived measurement value amongst farmers. The lack of validation, robustness, and high cost of state-of-the-art measurement technologies are further challenges to the optimisation of pasture measurement. The high spatial and temporal variability of grazed pasture has represented a significant hindrance to the precision of conventional grass measurement technologies. One perceived solution to overcome poor measurement precision relating to highly variable swards has been to increase measurement sampling rates and ultimately measurement labour. Measurement errors caused by sward heterogeneity, high labour cost, and the poor precision of conventional grass measurement methods have resulted in poor perceptions and low uptakes in grass 
measurement amongst farmers. Some of the state-of-the-art technologies discussed in this paper have the potential to overcome these issues. However, a period of time is required for long term studies that have performed sufficient validation of the proposed technologies to become established in the literature. A number of studies outlined in this review have indicated the detrimental effects that climate conditions, such as excessive cloud, wind, and rain, have on pasture sensing data. Additionally, the potential high cost of new grass measurement sensors will not alleviate the poor perception that some farmers have of the value of frequent grass measurement.

\section{Future of Grassland Measurement}

Within the literature outlined in this review, it is evident that there is considerable scope for the development of grassland sensing techniques to increase measurement precision, pasture mapping capabilities, and labour efficiency. Considerable potential exists to develop holistic grass measurement systems including multi-sensor configurations, which incorporate the benefits of a range of measurement technologies. Concurrently, the combination of new grassland sensing technologies with state-of-the-art modelling techniques should lead to more precise predictions of pasture parameters. This will enable the exploitation of a wide range of data sources, including measurement, management, and climate factors, which would be facilitated by online DSTs. Moreover, analysis of mixed species swards should be accounted for within the design and calibration of future grass measurement technologies. Regarding the new technologies discussed in this review, more detailed long-term studies that account for annual and seasonal sward variation are required.

Furthermore, scope exists to automate grass measurement using either manned or unmanned vehicles and this would aid the promotion of precision grass measurement amongst farmers. More research is required regarding the optimisation of grass measurement protocols that account for spatial and temporal heterogeneity in pasture in line with the principles of PA. The development of such protocols should be applicable to both herbage quantity and quality measurement techniques. The adoption of new precision grassland measurement technologies within pasture-based industries will only be justified if these technologies are proven to be significantly more precise and practical than established methods. Detailed cost-benefit analysis will be required to justify the implementation of new measurement technologies at farm level. Additionally, new measurement technologies will need to have minimal labour requirements, be easy to use, and adequate training will need to be provided to farmers to promote frequent measurement of pasture. This will further ensure that high resolution and accurate grassland data are regularly recorded.

\section{Conclusions}

This review summarised the basic principles of optimal grassland management on temperate pastures and the requirement for more precise and efficient measurement technologies in line with the concept of PA. The development of more robust and rapid technologies to predict pasture quantity and quality would enable the optimisation of herbage allocation and utilisation. Subsequently, this would lead to increases in profitability and reductions in emissions within pasture-based systems. The main findings from this review were:

- The dominant factors that need to be addressed with regard to the development of precision grassland measurement technologies are sward heterogeneity and measurement labour and cost

- There are no established technologies for determining real-time in-situ pasture quality. The development of such technologies is vital for a more precise management of pasture.

- The development and integration of holistic grassland management and measurement systems is necessary to achieve precision grassland management. 
Author Contributions: Conceptualization, D.J.M., M.D.M., B.O., M.O.; methodology, D.J.M., M.D.M., B.O., M.O.; software, D.J.M.; validation, M.D.M., B.O. and M.O.; formal analysis, D.J.M.; investigation, D.J.M.; resources, M.D.M., B.O., M.O.; data curation, D.J.M.; writing—original draft preparation, D.J.M.; writing—review and editing, B.O., M.D.M., M.O.D.; visualization, D.J.M.; supervision, D.J.M.; project administration, M.D.M., B.O.; funding acquisition, M.D.M., B.O. All authors have read and agreed to the published version of the manuscript.

Funding: This research was funded by the the ICT-AGRI GrassQ project (grant number 35779) and the Irish Department of Agriculture, Food and the Marine and the European Commission's ERA-NET, ICT-AGRI scheme as part of the Horizon 2020 programme.

Institutional Review Board Statement: Not applicable.

Informed Consent Statement: Not applicable.

Data Availability Statement: Not applicable.

Acknowledgments: This research was supported by the the ICT-AGRI GrassQ project (grant number 35779) and the Irish Department of Agriculture, Food and the Marine and the European Commission's ERA-NET, ICT-AGRI scheme as part of the Horizon 2020 programme.

Conflicts of Interest: The authors declare no conflict of interest.

\section{Appendix A}

Table A1. Summary of literature review dataset of studies relevant to grass measurement on temperate (Irish) grassland.

\begin{tabular}{|c|c|c|c|c|c|c|c|c|}
\hline Study & Year & Title & Study Focus & Region & $\begin{array}{l}\text { Grass } \\
\text { Species }\end{array}$ & $\begin{array}{l}\text { Measurement } \\
\text { System }\end{array}$ & $\begin{array}{l}\text { No. of } \\
\text { Grazing } \\
\text { Seasons }\end{array}$ & $\begin{array}{l}\text { Trial } \\
\text { Scale }\end{array}$ \\
\hline \multicolumn{9}{|c|}{ Grassland sward heterogeneity } \\
\hline $\begin{array}{l}\text { Jordan } \\
\text { et al. [34] }\end{array}$ & 2003 & $\begin{array}{l}\text { Sampling strategies } \\
\text { for mapping } \\
\text { "within-field" } \\
\text { variability in the dry } \\
\text { matter yield and } \\
\text { mineral nutrient } \\
\text { status of forage grass } \\
\text { crops in cool } \\
\text { temperate climes }\end{array}$ & $\begin{array}{c}\text { Develop a protocol } \\
\text { to measure and } \\
\text { map DM }\end{array}$ & Ireland & PRG & Herbage cuts & 1 & Paddock \\
\hline $\begin{array}{l}\text { Klootwijk } \\
\text { et al. [9] }\end{array}$ & 2019 & $\begin{array}{l}\text { Correcting fresh } \\
\text { grass allowance for } \\
\text { rejected patches due } \\
\text { to excreta in intensive } \\
\text { grazing systems for } \\
\text { dairy cows }\end{array}$ & $\begin{array}{l}\text { Measure the extent } \\
\text { of rejected patches } \\
\text { within pasture }\end{array}$ & $\begin{array}{l}\text { The } \\
\text { Netherlands }\end{array}$ & PRG & RPM & 2 & Paddock \\
\hline $\begin{array}{l}\text { Barthram } \\
\text { et al. [8] }\end{array}$ & 2005 & $\begin{array}{c}\text { Frequency } \\
\text { distributions of } \\
\text { sward height under } \\
\text { sheep grazing }\end{array}$ & $\begin{array}{l}\text { Measure the range } \\
\text { and distribution of } \\
\text { grass height within } \\
\text { pasture }\end{array}$ & Scotland & PRG/mixed & Sward stick & 2 & Paddock \\
\hline $\begin{array}{l}\text { Wilkinson } \\
\text { et al. [23] }\end{array}$ & 2014 & $\begin{array}{c}\text { Variation in } \\
\text { composition of } \\
\text { pre-grazed pasture } \\
\text { herbage in the United } \\
\text { Kingdom, 2006-2012 }\end{array}$ & $\begin{array}{l}\text { Measure the } \\
\text { variation of grass } \\
\text { quality in UK } \\
\text { pasture }\end{array}$ & UK & Mixed & NIRS & 7 & Paddock \\
\hline \multicolumn{9}{|c|}{ Conventional grass measurement systems } \\
\hline $\begin{array}{l}\text { Cayley \& } \\
\text { Bird [43] }\end{array}$ & 1996 & $\begin{array}{c}\text { Techniques for } \\
\text { measuring pastures }\end{array}$ & $\begin{array}{l}\text { Critical analysis of } \\
\text { conventional } \\
\text { pasture } \\
\text { measurement } \\
\text { techniques }\end{array}$ & Australia & - & $\begin{array}{c}\text { Herbage } \\
\text { cuts, RPM, } \\
\text { capacitance } \\
\text { meter, sward } \\
\text { stick }\end{array}$ & - & Paddock \\
\hline
\end{tabular}


Table A1. Cont.

\begin{tabular}{|c|c|c|c|c|c|c|c|c|}
\hline Study & Year & Title & Study Focus & Region & $\begin{array}{l}\text { Grass } \\
\text { Species }\end{array}$ & $\begin{array}{l}\text { Measurement } \\
\text { System }\end{array}$ & $\begin{array}{l}\text { No. of } \\
\text { Grazing } \\
\text { Seasons }\end{array}$ & $\begin{array}{l}\text { Trial } \\
\text { Scale }\end{array}$ \\
\hline $\begin{array}{l}\text { Klootwijk } \\
\text { et al. [28] }\end{array}$ & 2019 & $\begin{array}{c}\text { The effect of } \\
\text { intensive grazing } \\
\text { systems on the rising } \\
\text { plate meter } \\
\text { calibration for } \\
\text { perennial ryegrass } \\
\text { pastures }\end{array}$ & $\begin{array}{l}\text { Investigate the } \\
\text { effect of grazing } \\
\text { systems on RPM } \\
\text { calibration }\end{array}$ & $\begin{array}{l}\text { The } \\
\text { Netherlands }\end{array}$ & PRG & RPM & 2 & Paddock \\
\hline $\begin{array}{l}\text { Martin } \\
\text { et al. [42] }\end{array}$ & 2005 & $\begin{array}{l}\text { A comparison of } \\
\text { methods used to } \\
\text { determine biomass } \\
\text { on naturalized } \\
\text { swards }\end{array}$ & $\begin{array}{l}\text { Comparison of } \\
\text { conventional } \\
\text { pasture } \\
\text { measurement } \\
\text { methods }\end{array}$ & $\begin{array}{l}\text { Nova Scotia, } \\
\text { Canada }\end{array}$ & Mixed & $\begin{array}{l}\text { Visual } \\
\text { estimation, } \\
\text { sward stick, } \\
\text { RPM }\end{array}$ & 1 & Paddock \\
\hline $\begin{array}{c}\text { Mannetje } \\
{[44]}\end{array}$ & 2000 & $\begin{array}{l}\text { Measuring biomass } \\
\text { of grassland } \\
\text { vegetation }\end{array}$ & $\begin{array}{l}\text { Comparison of } \\
\text { conventional } \\
\text { pasture } \\
\text { measurement } \\
\text { methods }\end{array}$ & $\begin{array}{l}\text { The } \\
\text { Netherlands }\end{array}$ & - & $\begin{array}{c}\text { Visual } \\
\text { estimation, } \\
\text { sward stick, } \\
\text { RPM, remote } \\
\text { sensing }\end{array}$ & - & Paddock \\
\hline $\begin{array}{c}\text { Thomson } \\
\text { [45] }\end{array}$ & 1983 & $\begin{array}{l}\text { Factors influencing } \\
\text { the accuracy of } \\
\text { herbage mass } \\
\text { determinations with } \\
\text { a capacitance meter }\end{array}$ & $\begin{array}{c}\text { Calibration of } \\
\text { capacitance meter }\end{array}$ & $\begin{array}{l}\text { New } \\
\text { Zealand }\end{array}$ & Mixed & $\begin{array}{l}\text { Capacitance } \\
\text { meter }\end{array}$ & 2 & Paddock \\
\hline $\begin{array}{c}\text { Earle \& Mc } \\
\text { Gowan } \\
\text { [46] }\end{array}$ & 1979 & $\begin{array}{l}\text { Evaluation and } \\
\text { calibration of an } \\
\text { automated rising } \\
\text { plate meter for } \\
\text { estimating dry matter } \\
\text { yield of pasture }\end{array}$ & Calibration of RPM & $\begin{array}{l}\text { Victoria, } \\
\text { Australia }\end{array}$ & PRG & RPM & 2 & Paddock \\
\hline $\begin{array}{l}\text { Ferraro } \\
\text { et al. [47] }\end{array}$ & 2002 & $\begin{array}{l}\text { Seasonal variation in } \\
\text { the rising plate meter } \\
\text { calibration for forage } \\
\text { mass }\end{array}$ & Calibration of RPM & Ohio, USA & Mixed & RPM & 3 & Paddock \\
\hline $\begin{array}{c}\mathrm{O}^{\prime} \\
\text { Donovan } \\
\text { et al. [48] }\end{array}$ & 2002 & $\begin{array}{c}\text { Visual assessment of } \\
\text { herbage mass }\end{array}$ & $\begin{array}{c}\text { Calibration of } \\
\text { visual assessment }\end{array}$ & Ireland & PRG & $\begin{array}{c}\text { Visual } \\
\text { assessment }\end{array}$ & 2 & Paddock \\
\hline $\begin{array}{c}\text { O' } \\
\text { Donovan } \\
\text { et al. [26] }\end{array}$ & 2002 & $\begin{array}{l}\text { A comparison of four } \\
\text { methods of herbage } \\
\text { mass estimation }\end{array}$ & $\begin{array}{l}\text { Comparison of } \\
\text { conventional } \\
\text { pasture } \\
\text { measurement } \\
\text { methods }\end{array}$ & Ireland & PRG & $\begin{array}{l}\text { Visual } \\
\text { estimation, } \\
\text { sward stick, } \\
\text { RPM, } \\
\text { capacitance } \\
\text { meter }\end{array}$ & 2 & Paddock \\
\hline $\begin{array}{c}\text { Campbell } \\
\text { [49] }\end{array}$ & 1973 & $\begin{array}{l}\text { The visual } \\
\text { assessment of } \\
\text { pasture yield }\end{array}$ & $\begin{array}{c}\text { Calibration of } \\
\text { visual assessment }\end{array}$ & $\begin{array}{l}\text { Western, } \\
\text { Australia }\end{array}$ & Mixed & $\begin{array}{c}\text { Visual } \\
\text { assessment }\end{array}$ & 1 & Paddock \\
\hline $\begin{array}{c}\text { Stockdale } \\
\text { [50] }\end{array}$ & 1984 & $\begin{array}{c}\text { Evaluation of } \\
\text { techniques for } \\
\text { estimating the yield } \\
\text { of irrigated pastures } \\
\text { intensively grazed by } \\
\text { dairy cows } 1 . \text { Visual } \\
\text { assessment }\end{array}$ & $\begin{array}{l}\text { Assessment of } \\
\text { double sampling } \\
\text { technique } \\
\text { involving herbage } \\
\text { cuts and visual } \\
\text { assessment }\end{array}$ & $\begin{array}{l}\text { Victoria, } \\
\text { Australia }\end{array}$ & PRG/WC / & $\begin{array}{l}\text { herbage cuts } \\
\text { xednd visual } \\
\text { assessment }\end{array}$ & 1 & Paddock \\
\hline $\begin{array}{l}\text { L'Huillier } \\
\& \\
\text { Thomson } \\
\text { [51] }\end{array}$ & 1988 & $\begin{array}{c}\text { Estimation of } \\
\text { herbage mass in } \\
\text { ryegrass / white } \\
\text { clover dairy pastures }\end{array}$ & $\begin{array}{l}\text { Comparison of } \\
\text { conventional } \\
\text { pasture } \\
\text { measurement } \\
\text { methods }\end{array}$ & $\begin{array}{c}\text { New } \\
\text { Zealand }\end{array}$ & $\mathrm{PRG} / \mathrm{WC}$ & $\begin{array}{l}\text { Visual } \\
\text { estimation, } \\
\text { sward stick, } \\
\text { RPM, } \\
\text { capacitance } \\
\text { meter }\end{array}$ & 2 & Paddock \\
\hline
\end{tabular}


Table A1. Cont.

\begin{tabular}{|c|c|c|c|c|c|c|c|c|}
\hline Study & Year & Title & Study Focus & Region & $\begin{array}{c}\text { Grass } \\
\text { Species }\end{array}$ & $\begin{array}{l}\text { Measurement } \\
\text { System }\end{array}$ & $\begin{array}{l}\text { No. of } \\
\text { Grazing } \\
\text { Seasons }\end{array}$ & $\begin{array}{l}\text { Trial } \\
\text { Scale }\end{array}$ \\
\hline $\begin{array}{l}\text { Thomson } \\
\text { et al. [52] }\end{array}$ & 1997 & $\begin{array}{l}\text { Estimation of dairy } \\
\text { pastures-the need for } \\
\text { standardisation }\end{array}$ & $\begin{array}{c}\text { Investigate causes } \\
\text { of variation in } \\
\text { pasture } \\
\text { measurement } \\
\text { across regions }\end{array}$ & $\begin{array}{c}\text { New } \\
\text { Zealand }\end{array}$ & PRG/WC & $\begin{array}{l}\text { Visual } \\
\text { assessment, } \\
\text { RPM }\end{array}$ & 2 & Paddock \\
\hline $\begin{array}{l}\text { Lile et al. } \\
\quad[53]\end{array}$ & 2001 & $\begin{array}{l}\text { Practical use of the } \\
\text { rising plate meter } \\
\text { (RPM) on New } \\
\text { Zealand dairy farms }\end{array}$ & $\begin{array}{l}\text { Assess the } \\
\text { measurement } \\
\text { precision of the } \\
\text { RPM }\end{array}$ & $\begin{array}{l}\text { New } \\
\text { Zealand }\end{array}$ & PRG/WC & $\begin{array}{l}\text { Visual } \\
\text { assessment, } \\
\text { RPM }\end{array}$ & 3 & Paddock \\
\hline $\begin{array}{l}\text { O' Sullivan }^{\prime} \\
\text { et al. [54] }\end{array}$ & 1987 & $\begin{array}{l}\text { The Value of Pasture } \\
\text { Height in the } \\
\text { Measurement of Dry } \\
\text { Matter Yield }\end{array}$ & $\begin{array}{l}\text { Development of a } \\
\text { double sampling } \\
\text { technique for } \\
\text { measuring pasture }\end{array}$ & Ireland & PRG & $\begin{array}{l}\text { Herbage } \\
\text { cuts, RPM }\end{array}$ & 1 & Paddock \\
\hline $\begin{array}{l}\text { McSweeney } \\
\text { et al. [55] }\end{array}$ & 2019 & $\begin{array}{l}\text { Micro-sonic sensor } \\
\text { technology enables } \\
\text { enhanced grass } \\
\text { height measurement } \\
\text { by a Rising Plate } \\
\text { Meter }\end{array}$ & $\begin{array}{l}\text { Development of } \\
\text { GPS enabled rising } \\
\text { plate meter }\end{array}$ & Ireland & - & RPM & 1 & - \\
\hline $\begin{array}{l}\text { Defrance } \\
\text { et al. [56] }\end{array}$ & 2004 & $\begin{array}{l}\text { Greater } \\
\text { understanding the } \\
\text { density of grass to } \\
\text { calculate the growth } \\
\text { and biomass of a plot } \\
\text { and the stock of grass } \\
\text { available on a farm }\end{array}$ & $\begin{array}{l}\text { Calibration of } \\
\text { rising plate meter }\end{array}$ & France & PRG/WC & RPM & 13 & Paddock \\
\hline $\begin{array}{l}\text { Holshof } \\
\text { et al. [57] }\end{array}$ & 2015 & $\begin{array}{l}\text { Calibration of five } \\
\text { rising plate meters in } \\
\text { the Netherlands }\end{array}$ & $\begin{array}{c}\text { Comparison of } \\
\text { different rising } \\
\text { plate meter models }\end{array}$ & $\begin{array}{l}\text { The } \\
\text { Netherlands }\end{array}$ & PRG & RPM & 1 & Plots \\
\hline $\begin{array}{c}\text { Sanderson } \\
\text { et al. [27] }\end{array}$ & 2001 & $\begin{array}{l}\text { Estimating forage } \\
\text { mass with a } \\
\text { commercial } \\
\text { capacitance meter, } \\
\text { rising plate meter } \\
\text { and pasture ruler }\end{array}$ & $\begin{array}{l}\text { Comparison of } \\
\text { conventional } \\
\text { pasture } \\
\text { measurement } \\
\text { methods }\end{array}$ & Eastern, USA & Mixed & $\begin{array}{l}\text { Sward stick, } \\
\text { RPM, } \\
\text { capacitance } \\
\text { meter }\end{array}$ & 2 & Paddock \\
\hline $\begin{array}{l}\text { Creighton } \\
\text { et al. [21] }\end{array}$ & 2011 & $\begin{array}{l}\text { A survey analysis of } \\
\text { grassland dairy } \\
\text { farming in Ireland, } \\
\text { investigating } \\
\text { grassland } \\
\text { management, } \\
\text { technology adoption } \\
\text { and sward renewal }\end{array}$ & $\begin{array}{c}\text { Investigate } \\
\text { grassland } \\
\text { management } \\
\text { practices in Ireland }\end{array}$ & Ireland & PRG & - & 1 & Paddock \\
\hline $\begin{array}{l}\text { Murphy } \\
\text { et al. [59] }\end{array}$ & 2021 & $\begin{array}{l}\text { Utilising grassland } \\
\text { management and } \\
\text { climate data for more } \\
\text { accurate prediction of } \\
\text { herbage mass using } \\
\text { the rising plate meter }\end{array}$ & $\begin{array}{l}\text { Calibration of } \\
\text { rising plate meter } \\
\text { using state of the } \\
\text { art modelling } \\
\text { techniques }\end{array}$ & Ireland & PRG & RPM & 3 & $\begin{array}{l}\text { Paddock/ } \\
\text { Plots }\end{array}$ \\
\hline $\begin{array}{c}\text { Mannetje } \\
{[60]}\end{array}$ & 2002 & $\begin{array}{l}\text { Advances in } \\
\text { grassland science }\end{array}$ & $\begin{array}{c}\text { Review of } \\
\text { advancement of } \\
\text { grassland science } \\
\text { and measurement } \\
\text { techniques }\end{array}$ & $\begin{array}{l}\text { The } \\
\text { Netherlands }\end{array}$ & - & $\begin{array}{l}\text { Herbage } \\
\text { cuts, remote } \\
\text { sensing }\end{array}$ & - & Paddock \\
\hline $\begin{array}{l}\text { Beukes } \\
\text { et al. [22] }\end{array}$ & 2019 & $\begin{array}{l}\text { Regular estimates of } \\
\text { herbage mass can } \\
\text { improve profitability } \\
\text { of pasture-based } \\
\text { dairy systems }\end{array}$ & $\begin{array}{l}\text { Investigate the } \\
\text { effect of grass } \\
\text { measurement on } \\
\text { farm profitability }\end{array}$ & $\begin{array}{c}\text { New } \\
\text { Zealand }\end{array}$ & PRG & - & 1 & Paddock \\
\hline
\end{tabular}


Table A1. Cont.

\begin{tabular}{|c|c|c|c|c|c|c|c|c|}
\hline Study & Year & Title & Study Focus & Region & $\begin{array}{l}\text { Grass } \\
\text { Species }\end{array}$ & $\begin{array}{l}\text { Measurement } \\
\text { System }\end{array}$ & $\begin{array}{l}\text { No. of } \\
\text { Grazing } \\
\text { Seasons }\end{array}$ & $\begin{array}{l}\text { Trial } \\
\text { Scale }\end{array}$ \\
\hline \multicolumn{9}{|c|}{ Pasture sampling techniques } \\
\hline $\begin{array}{l}\text { Murphy } \\
\text { et al. [29] }\end{array}$ & 2020 & $\begin{array}{l}\text { Evaluation of the } \\
\text { precision of the rising } \\
\text { plate meter for } \\
\text { measuring } \\
\text { compressed sward } \\
\text { height on } \\
\text { heterogeneous } \\
\text { grassland swards }\end{array}$ & $\begin{array}{l}\text { Assessment of } \\
\text { RPM measurement } \\
\text { precision and } \\
\text { sampling protocol }\end{array}$ & Ireland & PRG/WC & RPM & 2 & $\begin{array}{l}\text { Paddock/ } \\
\text { Plot }\end{array}$ \\
\hline $\begin{array}{l}\text { Nakagami } \\
{[10]}\end{array}$ & 2016 & $\begin{array}{l}\text { A method for } \\
\text { approximate on-farm } \\
\text { estimation of herbage } \\
\text { mass by using two } \\
\text { assessments per } \\
\text { pasture }\end{array}$ & $\begin{array}{l}\text { Development of a } \\
\text { double } \\
\text { measurement } \\
\text { method for pasture }\end{array}$ & Japan & Mixed & $\begin{array}{c}\text { Visual } \\
\text { assessment, } \\
\text { herbage cuts, } \\
\text { RPM }\end{array}$ & 1 & Paddock \\
\hline $\begin{array}{l}\text { Hall et al. } \\
\text { [64] }\end{array}$ & 2019 & $\begin{array}{c}\text { Understanding } \\
\text { Tasmanian dairy } \\
\text { farmer adoption of } \\
\text { pasture management } \\
\text { practices: A Theory } \\
\text { of Planned Behaviour } \\
\text { approach }\end{array}$ & $\begin{array}{l}\text { Investigate farmer } \\
\text { behaviour with } \\
\text { regard the } \\
\text { adoption of grass } \\
\text { measurement } \\
\text { technology }\end{array}$ & Tasmania & - & - & 1 & Paddock \\
\hline $\begin{array}{l}\text { Eastwood } \\
\text { et al. [65] }\end{array}$ & 2020 & $\begin{array}{l}\text { Developing an } \\
\text { approach to assess } \\
\text { farmer perceptions of } \\
\text { the value of pasture } \\
\text { assessment } \\
\text { technologies }\end{array}$ & $\begin{array}{l}\text { Identify perceived } \\
\text { value of grass } \\
\text { measurement }\end{array}$ & $\begin{array}{l}\text { New } \\
\text { Zealand }\end{array}$ & - & - & 1 & Paddock \\
\hline $\begin{array}{l}\text { Hutchinson } \\
\text { [66] }\end{array}$ & 2016 & $\begin{array}{l}\text { A protocol for } \\
\text { sampling pastures in } \\
\text { hill country }\end{array}$ & $\begin{array}{l}\text { Develop a grass } \\
\text { measurement } \\
\text { protocol }\end{array}$ & $\begin{array}{c}\text { New } \\
\text { Zealand }\end{array}$ & Mixed & $\begin{array}{l}\text { RPM, } \\
\text { C-DAX }\end{array}$ & 3 & Paddock \\
\hline $\begin{array}{l}\text { Bernardi } \\
\text { et al. [68] }\end{array}$ & 2016 & $\begin{array}{l}\text { Spatial variability of } \\
\text { soil properties and } \\
\text { yield of a grazed } \\
\text { alfalfa pasture in } \\
\text { Brazil }\end{array}$ & $\begin{array}{c}\text { Map and evaluate } \\
\text { the spatial } \\
\text { variation of forage } \\
\text { yield }\end{array}$ & Brazil & Alfalfa & Herbage cuts & 1 & Paddock \\
\hline $\begin{array}{l}\text { Higgins \& } \\
\text { Bailey [69] }\end{array}$ & 2017 & $\begin{array}{l}\text { The role of precision } \\
\text { agriculture in } \\
\text { optimising soil } \\
\text { nutrient status and } \\
\text { grassland } \\
\text { productivity in } \\
\text { Northern Ireland, } \\
\text { while reducing } \\
\text { nutrient losses to air } \\
\text { or water }\end{array}$ & $\begin{array}{l}\text { Review of the } \\
\text { potential for } \\
\text { precision } \\
\text { agriculture in } \\
\text { grassland } \\
\text { agriculture }\end{array}$ & Ireland & - & - & - & Paddock \\
\hline $\begin{array}{l}\text { Deming } \\
\text { et al. [63] }\end{array}$ & 2018 & $\begin{array}{l}\text { Measuring labour } \\
\text { input on } \\
\text { pasture-based dairy } \\
\text { farms using a } \\
\text { smartphone }\end{array}$ & $\begin{array}{l}\text { Quantification of } \\
\text { labour input for } \\
\text { specific tasks on } \\
\text { Irish dairy farms }\end{array}$ & Ireland & PRG & $\begin{array}{l}\text { Herbage } \\
\text { cuts, RPM, } \\
\text { visual } \\
\text { assessment }\end{array}$ & 1 & Paddock \\
\hline \multicolumn{9}{|c|}{ State of the art grass measurement systems } \\
\hline $\begin{array}{l}\text { Togeiro de } \\
\text { Alckmin } \\
\text { et al. [58] }\end{array}$ & 2020 & $\begin{array}{l}\text { Comparing methods } \\
\text { to estimate perennial } \\
\text { ryegrass biomass: } \\
\text { canopy height and } \\
\text { spectral vegetation } \\
\text { indices }\end{array}$ & $\begin{array}{l}\text { Comparison of } \\
\text { RPM and remote } \\
\text { sensing }\end{array}$ & Tasmania & PRG & $\begin{array}{l}\text { RPM, hyper- } \\
\text { spectral }\end{array}$ & 1 & Plot \\
\hline
\end{tabular}


Table A1. Cont.

\begin{tabular}{|c|c|c|c|c|c|c|c|c|}
\hline Study & Year & Title & Study Focus & Region & $\begin{array}{l}\text { Grass } \\
\text { Species }\end{array}$ & $\begin{array}{l}\text { Measurement } \\
\text { System }\end{array}$ & $\begin{array}{l}\text { No. of } \\
\text { Grazing } \\
\text { Seasons }\end{array}$ & $\begin{array}{l}\text { Trial } \\
\text { Scale }\end{array}$ \\
\hline $\begin{array}{l}\text { Murphy } \\
\text { et al. [35] }\end{array}$ & 2020 & $\begin{array}{l}\text { Development of a } \\
\text { grass measurement } \\
\text { optimisation tool to } \\
\text { efficiently measure } \\
\text { herbage mass on } \\
\text { grazed pastures }\end{array}$ & $\begin{array}{l}\text { Development of a } \\
\text { decision support } \\
\text { tool to optimise } \\
\text { grass measurement }\end{array}$ & Ireland & PRG & RPM & 3 & $\begin{array}{l}\text { Paddock/ } \\
\text { Plot }\end{array}$ \\
\hline $\begin{array}{c}\text { Posudin } \\
\text { [70] }\end{array}$ & 2007 & $\begin{array}{c}\text { Practical } \\
\text { spectroscopy in } \\
\text { agriculture and food } \\
\text { science }\end{array}$ & $\begin{array}{l}\text { Review of the } \\
\text { fundamentals of } \\
\text { agri-spectroscopy }\end{array}$ & USA & - & NIRS & - & - \\
\hline $\begin{array}{l}\text { de Boever } \\
\text { et al. [72] }\end{array}$ & 1995 & $\begin{array}{l}\text { The use of NIRS to } \\
\text { predict the chemical } \\
\text { composition and the } \\
\text { energy value of } \\
\text { compound feeds for } \\
\text { cattle }\end{array}$ & $\begin{array}{l}\text { Development of } \\
\text { NIRS for } \\
\text { concentrate feed } \\
\text { quality analysis }\end{array}$ & Belgium & - & NIRS & - & - \\
\hline $\begin{array}{l}\text { Norris } \\
\text { et al. [73] }\end{array}$ & 1976 & $\begin{array}{l}\text { Predicting Forage } \\
\text { Quality by Infrared } \\
\text { Reflectance } \\
\text { Spectroscopy }\end{array}$ & $\begin{array}{l}\text { Development of } \\
\text { NIRS for dried and } \\
\text { milled forage } \\
\text { quality analysis }\end{array}$ & USA & - & NIRS & - & - \\
\hline $\begin{array}{l}\text { Lahart } \\
\text { et al. [74] }\end{array}$ & 2019 & $\begin{array}{l}\text { Predicting the dry } \\
\text { matter intake of } \\
\text { grazing dairy cows } \\
\text { using infrared } \\
\text { reflectance } \\
\text { spectroscopy analysis }\end{array}$ & $\begin{array}{l}\text { Development of } \\
\text { NIRS to predict dry } \\
\text { matter intake }\end{array}$ & Ireland & PRG/WC & NIRS & 3 & Paddock \\
\hline $\begin{array}{l}\text { Jafari et al. } \\
\text { [75] }\end{array}$ & 2003 & $\begin{array}{c}\text { A Note on } \\
\text { Estimation of Quality } \\
\text { Parameters in } \\
\text { Perennial Ryegrass } \\
\text { by near Infrared }\end{array}$ & $\begin{array}{l}\text { Development NIRS } \\
\text { calibrations to } \\
\text { predict quality of } \\
\text { dried and milled } \\
\text { grass }\end{array}$ & Ireland & PRG & NIRS & 2 & $\begin{array}{l}\text { Paddock/ } \\
\text { Plot }\end{array}$ \\
\hline $\begin{array}{l}\text { Burns et al. } \\
\text { [76] }\end{array}$ & 2014 & $\begin{array}{l}\text { A note on the } \\
\text { comparison of three } \\
\text { near infrared } \\
\text { reflectance } \\
\text { spectroscopy } \\
\text { calibration strategies } \\
\text { for assessing herbage } \\
\text { quality of ryegrass }\end{array}$ & $\begin{array}{l}\text { Development NIRS } \\
\text { calibrations to } \\
\text { predict quality of } \\
\text { dried and milled } \\
\text { grass }\end{array}$ & Ireland & $\begin{array}{l}\text { PRG, } \\
\text { Italian \& } \\
\text { hybrid } \\
\text { grass }\end{array}$ & NIRS & 2 & Plot \\
\hline $\begin{array}{l}\text { Burns et al. } \\
\text { [30] }\end{array}$ & 2013 & $\begin{array}{l}\text { Assessment of } \\
\text { herbage yield and } \\
\text { quality traits of } \\
\text { perennial ryegrasses } \\
\text { from a national } \\
\text { variety evaluation } \\
\text { scheme }\end{array}$ & $\begin{array}{l}\text { Development NIRS } \\
\text { calibrations to } \\
\text { predict quality of } \\
\text { dried and milled } \\
\text { grass }\end{array}$ & Ireland & PRG & NIRS & 3 & Plot \\
\hline $\begin{array}{l}\text { Alomar } \\
\text { et al. [77] }\end{array}$ & 2003 & $\begin{array}{l}\text { Effect of preparation } \\
\text { method on } \\
\text { composition and NIR } \\
\text { spectra of forage } \\
\text { samples }\end{array}$ & $\begin{array}{l}\text { Development NIRS } \\
\text { calibrations to } \\
\text { predict quality of } \\
\text { dried and milled } \\
\text { grass }\end{array}$ & Chile & Mixed & NIRS & 1 & Paddock \\
\hline $\begin{array}{l}\text { McClure } \\
\text { et al. [78] }\end{array}$ & 2002 & $\begin{array}{l}\text { Near infrared } \\
\text { technology for } \\
\text { precision } \\
\text { environmental } \\
\text { measurements: Part } \\
\text { 1. Determination of } \\
\text { nitrogen in green- } \\
\text { and dry-grass tissue }\end{array}$ & $\begin{array}{l}\text { Potential of NIRS } \\
\text { to analysis fresh } \\
\text { grass N content }\end{array}$ & Australia & Fescue & NIRS & 1 & Plot \\
\hline
\end{tabular}


Table A1. Cont.

\begin{tabular}{|c|c|c|c|c|c|c|c|c|}
\hline Study & Year & Title & Study Focus & Region & $\begin{array}{l}\text { Grass } \\
\text { Species }\end{array}$ & $\begin{array}{c}\text { Measurement } \\
\text { System }\end{array}$ & $\begin{array}{l}\text { No. of } \\
\text { Grazing } \\
\text { Seasons }\end{array}$ & $\begin{array}{l}\text { Trial } \\
\text { Scale }\end{array}$ \\
\hline $\begin{array}{c}\text { Reddersen } \\
\text { \& Wachen- } \\
\text { dorf } \\
{[79]}\end{array}$ & 2013 & $\begin{array}{l}\text { Effects of sample } \\
\text { preparation and } \\
\text { measurement } \\
\text { standardization on } \\
\text { the NIRS calibration } \\
\text { quality of nitrogen, } \\
\text { ash and NDFom } \\
\text { content in extensive } \\
\text { experimental } \\
\text { grassland biomass }\end{array}$ & $\begin{array}{c}\text { Development in } \\
\text { NIRS to analysis } \\
\text { standing sward } \\
\text { quality }\end{array}$ & Germany & Mixed & NIRS & 2 & Plot \\
\hline $\begin{array}{l}\text { Thomson } \\
\text { et al. [80] }\end{array}$ & 2018 & $\begin{array}{l}\text { Assessing the } \\
\text { accuracy of current } \\
\text { near infra-red } \\
\text { reflectance } \\
\text { spectroscopy analysis } \\
\text { for fresh grass-clover } \\
\text { mixture silages and } \\
\text { development of new } \\
\text { equations for this } \\
\text { purpose }\end{array}$ & $\begin{array}{l}\text { Development of } \\
\text { NIRS for } \\
\text { grass-clover silage } \\
\text { analysis }\end{array}$ & UK & Mixed/WC & NIRS & 3 & Paddock \\
\hline $\begin{array}{l}\text { Alomar } \\
\text { et al. [81] }\end{array}$ & 2009 & $\begin{array}{l}\text { Prediction of the } \\
\text { composition of fresh } \\
\text { pastures by near } \\
\text { infrared reflectance } \\
\text { or interactance- } \\
\text { reflectance } \\
\text { spectroscopy }\end{array}$ & $\begin{array}{l}\text { Development of } \\
\text { NIRS to analysis } \\
\text { fresh grass quality }\end{array}$ & Chile & Mixed & NIRS & 1 & Paddock \\
\hline $\begin{array}{c}\text { Dale et al. } \\
\text { [82] }\end{array}$ & 2017 & $\begin{array}{l}\text { Impact of sampling } \\
\text { and storage } \\
\text { technique, and } \\
\text { duration of storage, } \\
\text { on the composition } \\
\text { of fresh grass when } \\
\text { analysed using } \\
\text { near-infrared } \\
\text { reflectance } \\
\text { spectroscopy }\end{array}$ & $\begin{array}{l}\text { Use of fresh grass } \\
\text { NIRS to analysis } \\
\text { the impact of } \\
\text { sample storage and } \\
\text { preparation } \\
\text { techniques }\end{array}$ & Ireland & PRG & NIRS & 1 & Plot \\
\hline $\begin{array}{c}\text { Lobos et al. } \\
\text { [83] }\end{array}$ & 2019 & $\begin{array}{l}\text { Calibration models } \\
\text { for the nutritional } \\
\text { quality of fresh } \\
\text { pastures by } \\
\text { near-infrared } \\
\text { reflectance } \\
\text { spectroscopy }\end{array}$ & $\begin{array}{l}\text { Development of } \\
\text { NIRS to analysis } \\
\text { fresh grass quality }\end{array}$ & Chile & Mixed & NIRS & 2 & Paddock \\
\hline $\begin{array}{l}\text { Murphy } \\
\text { et al. [84] }\end{array}$ & 2021 & $\begin{array}{l}\text { A near infrared } \\
\text { spectroscopy } \\
\text { calibration for the } \\
\text { prediction of fresh } \\
\text { grass quality on Irish } \\
\text { pastures }\end{array}$ & $\begin{array}{l}\text { Development of } \\
\text { NIRS to analysis } \\
\text { fresh grass quality }\end{array}$ & Ireland & PRG & NIRS & 3 & $\begin{array}{l}\text { Paddock/ } \\
\text { Plot }\end{array}$ \\
\hline $\begin{array}{l}\text { Berzaghi } \\
\text { et al. [85] }\end{array}$ & 2005 & $\begin{array}{c}\text { Prediction } \\
\text { performances of } \\
\text { portable near } \\
\text { infrared instruments } \\
\text { for at farm forage } \\
\text { analysis }\end{array}$ & $\begin{array}{l}\text { Evaluation of } \\
\text { maize silage } \\
\text { quality with } \\
\text { portable NIRS }\end{array}$ & Italy & Maize & $\begin{array}{l}\text { Portable } \\
\text { NIRS }\end{array}$ & 3 & Paddock \\
\hline $\begin{array}{l}\text { Teixeira } \\
\text { et al. [86] }\end{array}$ & 2013 & $\begin{array}{l}\text { A review on the } \\
\text { applications of } \\
\text { portable } \\
\text { near-infrared } \\
\text { spectrometers in the } \\
\text { agro-food industry }\end{array}$ & $\begin{array}{c}\text { Review of the use } \\
\text { of NIRS in } \\
\text { Agriculture }\end{array}$ & Portugal & - & NIRS & - & - \\
\hline
\end{tabular}


Table A1. Cont.

\begin{tabular}{|c|c|c|c|c|c|c|c|c|}
\hline Study & Year & Title & Study Focus & Region & $\begin{array}{c}\text { Grass } \\
\text { Species }\end{array}$ & $\begin{array}{c}\text { Measurement } \\
\text { System }\end{array}$ & $\begin{array}{l}\text { No. of } \\
\text { Grazing } \\
\text { Seasons }\end{array}$ & $\begin{array}{l}\text { Trial } \\
\text { Scale }\end{array}$ \\
\hline $\begin{array}{l}\text { Feuerstein } \\
\& \text { Paul [87] }\end{array}$ & 2007 & $\begin{array}{c}\text { NIR-Spectroscopy of } \\
\text { non-dried forages as } \\
\text { a tool in breeding for } \\
\text { higher } \\
\text { quality-laboratory } \\
\text { tests and online } \\
\text { investigations on plot } \\
\text { harvesters }\end{array}$ & $\begin{array}{c}\text { Development of } \\
\text { portable NIRS to } \\
\text { analysis fresh grass } \\
\text { quality }\end{array}$ & Germany & Mixed & $\begin{array}{l}\text { Portable } \\
\text { NIRS }\end{array}$ & 6 & Plot \\
\hline $\begin{array}{l}\text { Mendarte } \\
\text { et al. [88] }\end{array}$ & 2010 & $\begin{array}{l}\text { Use of portable NIRS } \\
\text { equipment in field } \\
\text { conditions to } \\
\text { determine the } \\
\text { nutritional value of } \\
\text { mountain pastures }\end{array}$ & $\begin{array}{c}\text { Development of } \\
\text { portable NIRS to } \\
\text { analysis fresh grass } \\
\text { quality }\end{array}$ & $\begin{array}{l}\text { Basque } \\
\text { Country }\end{array}$ & Mixed & $\begin{array}{l}\text { Portable } \\
\text { NIRS }\end{array}$ & 1 & Paddock \\
\hline $\begin{array}{l}\text { Smith et al. } \\
\text { [89] }\end{array}$ & 2020 & $\begin{array}{l}\text { Machine learning } \\
\text { algorithms to predict } \\
\text { forage nutritive value } \\
\text { of in situ perennial } \\
\text { ryegrass plants using } \\
\text { hyperspectral canopy } \\
\text { reflectance data }\end{array}$ & $\begin{array}{l}\text { Development of } \\
\text { hyperspectral } \\
\text { sensing for grass } \\
\text { quality analysis }\end{array}$ & $\begin{array}{l}\text { Victoria, } \\
\text { Australia }\end{array}$ & PRG & Hyperspectral & 1 & Plot \\
\hline $\begin{array}{l}\text { Bell et al. } \\
\quad \text { [90] }\end{array}$ & 2018 & $\begin{array}{l}\text { The Use of Mobile } \\
\text { Near-Infrared } \\
\text { Spectroscopy for } \\
\text { Real-Time Pasture } \\
\text { Management }\end{array}$ & $\begin{array}{c}\text { Development of } \\
\text { portable NIRS to } \\
\text { analysis fresh grass } \\
\text { quality }\end{array}$ & UK & Mixed/PR & $\begin{array}{l}\text { Portable } \\
\text { NIRS }\end{array}$ & 1 & Paddock \\
\hline $\begin{array}{l}\text { Patton } \\
\text { et al. [91] }\end{array}$ & 2018 & $\begin{array}{l}\text { Portable NIRS: a } \\
\text { novel technology for } \\
\text { the prediction of } \\
\text { forage nutritive } \\
\text { quality }\end{array}$ & $\begin{array}{l}\text { Assessment of } \\
\text { portable NIRS for } \\
\text { fresh grass quality } \\
\text { analysis }\end{array}$ & Ireland & PRG & $\begin{array}{l}\text { Portable } \\
\text { NIRS }\end{array}$ & 1 & Paddock \\
\hline $\begin{array}{c}\text { Hart et al. } \\
\text { [92] }\end{array}$ & 2020 & $\begin{array}{c}\text { Comparison of } \\
\text { Spectral } \\
\text { Reflectance-Based } \\
\text { Smart Farming Tools } \\
\text { and a Conventional } \\
\text { Approach to } \\
\text { Determine Herbage } \\
\text { Mass and Grass } \\
\text { Quality on Farm }\end{array}$ & $\begin{array}{l}\text { Comparison of } \\
\text { remote sensing and } \\
\text { conventional grass } \\
\text { measurement } \\
\text { technologies }\end{array}$ & Switzerland & Mixed & $\begin{array}{l}\text { Portable } \\
\text { NIRS, Multi- } \\
\text { spectral }\end{array}$ & 1 & Plot \\
\hline $\begin{array}{l}\text { Vogel et al. } \\
\text { [93] }\end{array}$ & 2019 & $\begin{array}{l}\text { Evaluating } \\
\text { Soil-Borne Causes of } \\
\text { Biomass Variability } \\
\text { in Grassland by } \\
\text { Remote and Proximal } \\
\text { Sensing }\end{array}$ & $\begin{array}{l}\text { Use of } \\
\text { multispectral UAV } \\
\text { and proximal } \\
\text { sensing to evaluate } \\
\text { biomass variability }\end{array}$ & Germany & Mixed & $\begin{array}{c}\text { Multispectral, } \\
\text { proximal } \\
\text { sensing }\end{array}$ & 1 & Paddock \\
\hline $\begin{array}{l}\text { Reddersen } \\
\text { et al. [94] }\end{array}$ & 2014 & $\begin{array}{l}\text { A multi-sensor } \\
\text { approach for } \\
\text { predicting biomass of } \\
\text { extensively managed } \\
\text { grassland }\end{array}$ & $\begin{array}{l}\text { The use of } \\
\text { hyperspectral } \\
\text { sensing and } \\
\text { ultrasound to } \\
\text { predict grass } \\
\text { quality and } \\
\text { quantity }\end{array}$ & Germany & Mixed & $\begin{array}{l}\text { Ultrasound, } \\
\text { Hyperspec- } \\
\text { tral }\end{array}$ & 2 & Plot \\
\hline $\begin{array}{c}\text { Safari et al. } \\
\text { [96] }\end{array}$ & 2016 & $\begin{array}{l}\text { Comparing mobile } \\
\text { and static assessment } \\
\text { of biomass in } \\
\text { heterogeneous } \\
\text { grassland with a } \\
\text { multi-sensor system }\end{array}$ & $\begin{array}{l}\text { The use of a mobile } \\
\text { muti-sensor unit to } \\
\text { measure grass } \\
\text { quantity and } \\
\text { quality }\end{array}$ & Germany & Mixed & $\begin{array}{l}\text { Ultrasound, } \\
\text { Hyperspec- } \\
\text { tral }\end{array}$ & 2 & Paddock \\
\hline
\end{tabular}


Table A1. Cont.

\begin{tabular}{|c|c|c|c|c|c|c|c|c|}
\hline Study & Year & Title & Study Focus & Region & $\begin{array}{l}\text { Grass } \\
\text { Species }\end{array}$ & $\begin{array}{l}\text { Measurement } \\
\text { System }\end{array}$ & $\begin{array}{l}\text { No. of } \\
\text { Grazing } \\
\text { Seasons }\end{array}$ & $\begin{array}{l}\text { Trial } \\
\text { Scale }\end{array}$ \\
\hline $\begin{array}{l}\text { Moeckel } \\
\text { et al. [97] }\end{array}$ & 2017 & $\begin{array}{l}\text { Fusion of Ultrasonic } \\
\text { and Spectral Sensor } \\
\text { Data for Improving } \\
\text { the Estimation of } \\
\text { Biomass in } \\
\text { Grasslands with } \\
\text { Heterogeneous } \\
\text { Sward Structure }\end{array}$ & $\begin{array}{l}\text { The use of } \\
\text { hyperspectral } \\
\text { sensing and } \\
\text { ultrasound to } \\
\text { predict grass } \\
\text { quality and } \\
\text { quantity }\end{array}$ & Germany & Mixed & $\begin{array}{l}\text { Ultrasound, } \\
\text { Hyperspec- } \\
\text { tral }\end{array}$ & 1 & Paddock \\
\hline $\begin{array}{l}\text { Legg \& } \\
\text { Bradley } \\
\text { [98] }\end{array}$ & 2019 & $\begin{array}{l}\text { Ultrasonic Proximal } \\
\text { Sensing of Pasture } \\
\text { Biomass }\end{array}$ & $\begin{array}{l}\text { Development of } \\
\text { ultrasonic sensors } \\
\text { for rapid } \\
\text { measurement of } \\
\text { grass height }\end{array}$ & $\begin{array}{c}\text { New } \\
\text { Zealand }\end{array}$ & PRG & Ultrasound & 1 & Plot \\
\hline $\begin{array}{l}\text { Rennie } \\
\text { et al. [99] }\end{array}$ & 2009 & $\begin{array}{l}\text { Calibration of the } \\
\text { C-DAX Rapid } \\
\text { Pasturemeter and the } \\
\text { rising plate meter for } \\
\text { kikuyu-based } \\
\text { Northland dairy } \\
\text { pastures }\end{array}$ & $\begin{array}{l}\text { Calibration of the } \\
\text { C-DAX to measure } \\
\text { grass quantity }\end{array}$ & $\begin{array}{l}\text { New } \\
\text { Zealand }\end{array}$ & PRG/WC & C-DAX & 1 & Paddock \\
\hline $\begin{array}{l}\text { Lawrence } \\
\text { et al. [100] }\end{array}$ & 2007 & $\begin{array}{l}\text { Pasture Monitoring } \\
\text { Technologies }\end{array}$ & $\begin{array}{l}\text { Review of } \\
\text { precision } \\
\text { agriculture tools } \\
\text { for pasture } \\
\text { measurement and } \\
\text { mapping }\end{array}$ & $\begin{array}{l}\text { New } \\
\text { Zealand }\end{array}$ & - & $\begin{array}{l}\text { C-DAX, } \\
\text { NIRS }\end{array}$ & - & Paddock \\
\hline $\begin{array}{l}\text { King et al. } \\
\text { [101] }\end{array}$ & 2010 & $\begin{array}{c}\text { Pasture Mass } \\
\text { Estimation by the } \\
\text { C-DAX Pasture } \\
\text { Meter: Regional } \\
\text { Calibrations for New } \\
\text { Zealand }\end{array}$ & $\begin{array}{l}\text { Comparison of } \\
\text { RPM, C-AX and } \\
\text { herbage cuts for } \\
\text { grass measurement }\end{array}$ & $\begin{array}{l}\text { New } \\
\text { Zealand }\end{array}$ & $\mathrm{PRG} / \mathrm{WC} / \mathrm{N}$ & xedC-DAX & 1 & Paddock \\
\hline $\begin{array}{l}\text { Oudshoorn } \\
\text { et al. [102] }\end{array}$ & 2011 & $\begin{array}{l}\text { Calibration of the } \\
\text { C-DAX pasture } \\
\text { meter in a Danish } \\
\text { grazing system }\end{array}$ & $\begin{array}{l}\text { Calibration of } \\
\text { C-DAX for grass } \\
\text { quantity } \\
\text { measurement }\end{array}$ & Denmark & PRG/WC & C-DAX & 2 & Plot \\
\hline $\begin{array}{l}\text { Schori et al. } \\
\text { [103] }\end{array}$ & 2015 & $\begin{array}{l}\text { Sward surface height } \\
\text { estimation with a } \\
\text { rising plate meter } \\
\text { and the C-Dax } \\
\text { Pasturemeter }\end{array}$ & $\begin{array}{l}\text { Comparison of } \\
\text { RPM and C-DAX } \\
\text { for grass } \\
\text { measurement }\end{array}$ & Switzerland & Mixed & C-DAX & 4 & Paddock \\
\hline $\begin{array}{l}\text { Dennis } \\
\text { et al. [104] }\end{array}$ & 2015 & $\begin{array}{c}\text { Pasture yield } \\
\text { mapping: why \& } \\
\text { how }\end{array}$ & $\begin{array}{l}\text { Development of } \\
\text { measurement } \\
\text { protocol for the } \\
\text { C-DAX to map } \\
\text { pasture yield }\end{array}$ & $\begin{array}{l}\text { New } \\
\text { Zealand }\end{array}$ & - & C-DAX & 2 & Paddock \\
\hline $\begin{array}{l}\text { Manderson } \\
\text { \& Hunt } \\
\text { [105] }\end{array}$ & 2013 & $\begin{array}{l}\text { Introducing the } \\
\text { Agri-Rover: An } \\
\text { Autonomous } \\
\text { on-the-go sensing } \\
\text { rover for science and } \\
\text { farming }\end{array}$ & $\begin{array}{l}\text { Automation of } \\
\text { C-DAX using } \\
\text { robotics }\end{array}$ & $\begin{array}{l}\text { New } \\
\text { Zealand }\end{array}$ & - & C-DAX & - & Paddock \\
\hline $\begin{array}{l}\text { Gobor et al. } \\
\text { [106] }\end{array}$ & 2015 & $\begin{array}{l}\text { Advanced pasture } \\
\text { management through } \\
\text { innovative robotic } \\
\text { pasture maintenance }\end{array}$ & $\begin{array}{l}\text { Development of } \\
\text { pasture care and } \\
\text { management } \\
\text { robots }\end{array}$ & Germany & Mixed & Laser, NIRS & 1 & Paddock \\
\hline $\begin{array}{l}\text { Marin et al. } \\
\text { [107] }\end{array}$ & 2018 & $\begin{array}{c}\text { Urban Lawn } \\
\text { Monitoring in Smart } \\
\text { City Environments }\end{array}$ & $\begin{array}{l}\text { Comparison of } \\
\text { remote and ground } \\
\text { automated grass } \\
\text { measurement }\end{array}$ & Spain & - & RGB sensing & 1 & Plot \\
\hline
\end{tabular}


Table A1. Cont.

\begin{tabular}{|c|c|c|c|c|c|c|c|c|}
\hline Study & Year & Title & Study Focus & Region & $\begin{array}{c}\text { Grass } \\
\text { Species }\end{array}$ & $\begin{array}{l}\text { Measurement } \\
\text { System }\end{array}$ & $\begin{array}{l}\text { No. of } \\
\text { Grazing } \\
\text { Seasons }\end{array}$ & $\begin{array}{l}\text { Trial } \\
\text { Scale }\end{array}$ \\
\hline $\begin{array}{l}\text { Viscarra } \\
\text { Rossel et al. } \\
\text { [109] }\end{array}$ & 2011 & $\begin{array}{l}\text { Proximal Soil } \\
\text { Sensing: An Effective } \\
\text { Approach for Soil } \\
\text { Measurements in } \\
\text { Space and Time }\end{array}$ & $\begin{array}{c}\text { Calibration of } \\
\text { proximal sensing } \\
\text { techniques for soil } \\
\text { analysis }\end{array}$ & $\begin{array}{c}\text { France, } \\
\text { Australia }\end{array}$ & - & NIRS & - & - \\
\hline $\begin{array}{l}\text { Pullanagari } \\
\text { et al. [110] }\end{array}$ & 2012 & $\begin{array}{l}\text { In-field hyperspectral } \\
\text { proximal sensing for } \\
\text { estimating quality } \\
\text { parameters of mixed } \\
\text { pasture }\end{array}$ & $\begin{array}{c}\text { Calibration of } \\
\text { hyperspectral } \\
\text { sensing for grass } \\
\text { quality } \\
\text { measurement }\end{array}$ & $\begin{array}{l}\text { New } \\
\text { Zealand }\end{array}$ & Mixed & Hyperspectral & 1 & Paddock \\
\hline $\begin{array}{l}\text { Ancin- } \\
\text { Murguzur } \\
\text { et al. [111] }\end{array}$ & 2019 & $\begin{array}{c}\text { Yield Estimates by a } \\
\text { Two-Step Approach } \\
\text { Using Hyperspectral } \\
\text { Methods in } \\
\text { Grasslands at High } \\
\text { Latitudes }\end{array}$ & $\begin{array}{l}\text { Calibration of } \\
\text { proximal and } \\
\text { satellite } \\
\text { hyperspectral } \\
\text { sensing for grass } \\
\text { measurement }\end{array}$ & Norway & Mixed & Hyperspectral & 4 & Paddock \\
\hline $\begin{array}{l}\text { Pullanagari } \\
\text { et al. [112] }\end{array}$ & 2011 & $\begin{array}{l}\text { Pasture quality } \\
\text { measurement tools } \\
\text { for decision making }\end{array}$ & $\begin{array}{l}\text { Investigation of } \\
\text { optical sensor for } \\
\text { the measurement } \\
\text { of pasture quality }\end{array}$ & $\begin{array}{l}\text { New } \\
\text { Zealand }\end{array}$ & - & $\begin{array}{l}\text { Multispectral, } \\
\text { Hyperspec- } \\
\text { tral }\end{array}$ & 1 & Paddock \\
\hline $\begin{array}{l}\text { Askari } \\
\text { et al. [113] }\end{array}$ & 2019 & $\begin{array}{c}\text { Evaluation of Grass } \\
\text { Quality under } \\
\text { Different Soil } \\
\text { Management } \\
\text { Scenarios Using } \\
\text { Remote Sensing } \\
\text { Techniques }\end{array}$ & $\begin{array}{l}\text { Calibration of } \\
\text { proximal and } \\
\text { remote sensing } \\
\text { methods for } \\
\text { pasture quantity } \\
\text { and quality } \\
\text { measurement }\end{array}$ & Ireland & PRG/WC & $\begin{array}{l}\text { Multispectral, } \\
\text { Hyperspec- } \\
\text { tral }\end{array}$ & 2 & Paddock \\
\hline $\begin{array}{l}\text { Rueda- } \\
\text { Ayala et al. } \\
\text { [108] }\end{array}$ & 2019 & $\begin{array}{c}\text { Comparing } \\
\text { UAV-Based } \\
\text { Technologies and } \\
\text { RGB-D } \\
\text { Reconstruction } \\
\text { Methods for Plant } \\
\text { Height and Biomass } \\
\text { Monitoring on Grass } \\
\text { Ley }\end{array}$ & $\begin{array}{l}\text { Evaluation of aerial } \\
\text { and ground based } \\
\text { method for grass } \\
\text { quantity } \\
\text { measurement }\end{array}$ & Norway & Mixed & $\begin{array}{l}\text { RGB-Depth } \\
\text { sensor }\end{array}$ & 1 & Paddock \\
\hline $\begin{array}{l}\text { Capolupo } \\
\text { et al. [114] }\end{array}$ & 2015 & $\begin{array}{l}\text { Estimating Plant } \\
\text { Traits of Grasslands } \\
\text { from UAV-Acquired } \\
\text { Hyperspectral } \\
\text { Images: A } \\
\text { Comparison of } \\
\text { Statistical } \\
\text { Approaches }\end{array}$ & $\begin{array}{c}\text { Statistical } \\
\text { modelling methods } \\
\text { for hyperspectral } \\
\text { grass measurement } \\
\text { data }\end{array}$ & Germany & - & Hyperspectral & 1 & Plot \\
\hline $\begin{array}{l}\text { Pullanagari } \\
\text { et al. [115] }\end{array}$ & 2012 & $\begin{array}{l}\text { Proximal sensing of } \\
\text { the seasonal } \\
\text { variability of pasture } \\
\text { nutritive value using } \\
\text { multispectral } \\
\text { radiometry }\end{array}$ & $\begin{array}{l}\text { Measuring the } \\
\text { variability of } \\
\text { pasture quality } \\
\text { using proximal } \\
\text { sensing }\end{array}$ & $\begin{array}{l}\text { New } \\
\text { Zealand }\end{array}$ & PRG/WC & Multispectral & 1 & Paddock \\
\hline $\begin{array}{l}\text { Oliveira } \\
\text { et al. [116] }\end{array}$ & 2020 & $\begin{array}{l}\text { Machine learning } \\
\text { estimators for the } \\
\text { quantity and quality } \\
\text { of grass swards used } \\
\text { for silage production } \\
\text { using drone-based } \\
\text { imaging } \\
\text { spectrometry and } \\
\text { photogrammetry }\end{array}$ & $\begin{array}{l}\text { Utilisation of UAV } \\
\text { sensing to measure } \\
\text { silage grass quality }\end{array}$ & Finland & Mixed & $\begin{array}{l}\text { RGB, Hyper- } \\
\text { spectral }\end{array}$ & 1 & Paddock \\
\hline
\end{tabular}


Table A1. Cont.

\begin{tabular}{|c|c|c|c|c|c|c|c|c|}
\hline Study & Year & Title & Study Focus & Region & $\begin{array}{c}\text { Grass } \\
\text { Species }\end{array}$ & $\begin{array}{l}\text { Measurement } \\
\text { System }\end{array}$ & $\begin{array}{l}\text { No. of } \\
\text { Grazing } \\
\text { Seasons }\end{array}$ & $\begin{array}{l}\text { Trial } \\
\text { Scale }\end{array}$ \\
\hline $\begin{array}{l}\text { Obanawa } \\
\text { et al. [117] }\end{array}$ & 2020 & $\begin{array}{c}\text { Portable } \\
\text { LiDAR-Based } \\
\text { Method for } \\
\text { Improvement of } \\
\text { Grass Height } \\
\text { Measurement } \\
\text { Accuracy: } \\
\text { Comparison with } \\
\text { SfM Methods }\end{array}$ & $\begin{array}{l}\text { Development of } \\
\text { LiDAR to measure } \\
\text { grass height }\end{array}$ & Japan & $\begin{array}{l}\text { Italian } \\
\text { ryegrass }\end{array}$ & LiDAR & 1 & Plot \\
\hline $\begin{array}{l}\text { Vázquez- } \\
\text { Arellano } \\
\text { et al. [118] }\end{array}$ & 2016 & $\begin{array}{c}\text { 3-D Imaging Systems } \\
\text { for Agricultural } \\
\text { Applications-A } \\
\text { Review }\end{array}$ & $\begin{array}{l}\text { Review of 3D } \\
\text { image technology } \\
\text { for precision } \\
\text { agriculture } \\
\text { applications }\end{array}$ & Germany & - & $\begin{array}{l}\text { 3-D imaging } \\
\text { systems }\end{array}$ & - & Paddock \\
\hline $\begin{array}{c}\text { Cooper } \\
\text { et al. [119] }\end{array}$ & 2017 & $\begin{array}{l}\text { Examination of the } \\
\text { potential of terrestrial } \\
\text { laser scanning and } \\
\text { structure-from- } \\
\text { motion } \\
\text { photogrammetry for } \\
\text { rapid } \\
\text { non-destructive field } \\
\text { measurement of } \\
\text { grass biomass }\end{array}$ & $\begin{array}{l}\text { Comparison of } \\
\text { LiDAR and RPM } \\
\text { for grass quantity } \\
\text { measurement }\end{array}$ & $\begin{array}{c}\text { South } \\
\text { Dakota, USA }\end{array}$ & $\begin{array}{l}\text { Smooth } \\
\text { Brome }\end{array}$ & LiDAR, RPM & 1 & Plot \\
\hline $\begin{array}{l}\text { Sibanda } \\
\text { et al. [120] }\end{array}$ & 2016 & $\begin{array}{l}\text { Comparing the } \\
\text { spectral settings of } \\
\text { the new generation } \\
\text { broad and narrow } \\
\text { band sensors in } \\
\text { estimating biomass } \\
\text { of native grasses } \\
\text { grown under } \\
\text { different } \\
\text { management } \\
\text { practices }\end{array}$ & $\begin{array}{l}\text { Comparison of } \\
\text { proximal and } \\
\text { satellite sensing for } \\
\text { grass quantity } \\
\text { measurement }\end{array}$ & South Africa & Mixed & $\begin{array}{l}\text { Multispectral, } \\
\text { Hyperspec- } \\
\text { tral }\end{array}$ & 1 & Plot \\
\hline $\begin{array}{c}\text { Barrett } \\
\text { et al. [122] }\end{array}$ & 2014 & $\begin{array}{c}\text { Assessment of } \\
\text { multi-temporal, } \\
\text { multi-sensor radar } \\
\text { and ancillary spatial } \\
\text { data for grasslands } \\
\text { monitoring in Ireland } \\
\text { using machine } \\
\text { learning approaches }\end{array}$ & $\begin{array}{l}\text { Calibration of } \\
\text { satellite radar for } \\
\text { grassland } \\
\text { classification }\end{array}$ & Ireland & PRG/WC & $\begin{array}{l}\text { Satellite } \\
\text { radar }\end{array}$ & - & Paddock \\
\hline $\begin{array}{c}\text { Ali et al. } \\
\text { [123] }\end{array}$ & 2017 & $\begin{array}{c}\text { Application of } \\
\text { Repeat-Pass } \\
\text { TerraSAR-X Staring } \\
\text { Spotlight } \\
\text { Interferometric } \\
\text { Coherence to } \\
\text { Monitor Pasture } \\
\text { Biophysical } \\
\text { Parameters: } \\
\text { Limitations and } \\
\text { Sensitivity Analysis }\end{array}$ & $\begin{array}{l}\text { Calibration of } \\
\text { satellite radar for } \\
\text { grass quantity } \\
\text { measurement }\end{array}$ & Ireland & PRG & $\begin{array}{l}\text { Satellite } \\
\text { radar }\end{array}$ & 1 & Paddock \\
\hline
\end{tabular}


Table A1. Cont.

\begin{tabular}{|c|c|c|c|c|c|c|c|c|}
\hline Study & Year & Title & Study Focus & Region & $\begin{array}{l}\text { Grass } \\
\text { Species }\end{array}$ & $\begin{array}{l}\text { Measurement } \\
\text { System }\end{array}$ & $\begin{array}{l}\text { No. of } \\
\text { Grazing } \\
\text { Seasons }\end{array}$ & $\begin{array}{l}\text { Trial } \\
\text { Scale }\end{array}$ \\
\hline \multicolumn{9}{|c|}{ Grass measurement decision support systems } \\
\hline $\begin{array}{l}\text { Hanrahan } \\
\text { et al. [20] }\end{array}$ & 2017 & $\begin{array}{l}\text { PastureBase Ireland: } \\
\text { A grassland decision } \\
\text { support system and } \\
\text { national database }\end{array}$ & $\begin{array}{l}\text { Development of } \\
\text { grassland } \\
\text { management } \\
\text { decision support } \\
\text { tool and national } \\
\text { database }\end{array}$ & Ireland & PRG & $\begin{array}{l}\text { Rising plate } \\
\text { meter, Visual } \\
\text { estimation }\end{array}$ & 2 & $\begin{array}{l}\text { Paddock/ } \\
\text { Plot }\end{array}$ \\
\hline $\begin{array}{l}\text { Delaby } \\
\text { et al. [124] }\end{array}$ & 2015 & $\begin{array}{l}\text { Pastur'Plan: a } \\
\text { dynamic tool to } \\
\text { support grazing } \\
\text { management } \\
\text { decision making in a } \\
\text { rotational grazing } \\
\text { system }\end{array}$ & $\begin{array}{l}\text { Introduction to a } \\
\text { decision support } \\
\text { tool for grassland } \\
\text { measurement and } \\
\text { management }\end{array}$ & France & - & RPM & - & Paddock \\
\hline $\begin{array}{c}\text { Zom \& } \\
\text { Holshof } \\
\text { [125] }\end{array}$ & 2011 & $\begin{array}{l}\text { GrazeVision: A } \\
\text { versatile grazing } \\
\text { decision support } \\
\text { model }\end{array}$ & $\begin{array}{l}\text { Development of a } \\
\text { decision support } \\
\text { model for } \\
\text { grassland } \\
\text { management }\end{array}$ & $\begin{array}{l}\text { The } \\
\text { Netherlands }\end{array}$ & - & - & - & Paddock \\
\hline $\begin{array}{c}\mathrm{O}^{\prime} \text { Leary \& } \\
\mathrm{O}^{\prime} \\
\text { Donovan } \\
\text { [127] }\end{array}$ & 2019 & $\begin{array}{l}\text { PastureBase } \\
\text { Ireland-getting } \\
\text { Ireland utilising more } \\
\text { grass. Moorepark '19 } \\
\text { Irish Dairy }\end{array}$ & $\begin{array}{l}\text { Development of } \\
\text { grassland } \\
\text { management } \\
\text { decision support } \\
\text { tool and national } \\
\text { database }\end{array}$ & Ireland & PRG & $\begin{array}{l}\text { Rising plate } \\
\text { meter, Visual } \\
\text { estimation }\end{array}$ & - & Paddock \\
\hline $\begin{array}{l}\text { McDonnell } \\
\text { et al. [128] }\end{array}$ & 2019 & $\begin{array}{l}\text { Weather forecasts to } \\
\text { enhance an Irish } \\
\text { grass growth model }\end{array}$ & $\begin{array}{l}\text { The use of weather } \\
\text { forecasting to } \\
\text { predict grass } \\
\text { growth }\end{array}$ & Ireland & PRG & $\begin{array}{l}\text { Grass } \\
\text { growth } \\
\text { model }\end{array}$ & 4 & Paddock \\
\hline $\begin{array}{l}\text { Ruelle et al. } \\
\text { [129] }\end{array}$ & 2018 & $\begin{array}{l}\text { Development of the } \\
\text { Moorepark St Gilles } \\
\text { grass growth model } \\
\text { (MoSt GG model): A } \\
\text { predictive model for } \\
\text { grass growth for } \\
\text { pasture based } \\
\text { systems }\end{array}$ & $\begin{array}{l}\text { Development of a } \\
\text { grass growth } \\
\text { model for Irish } \\
\text { pasture }\end{array}$ & Ireland & PRG & $\begin{array}{l}\text { Grass } \\
\text { growth } \\
\text { model }\end{array}$ & 2 & Paddock \\
\hline $\begin{array}{l}\text { Romera } \\
\text { et al. [130] }\end{array}$ & 2010 & $\begin{array}{l}\text { Use of a pasture } \\
\text { growth model to } \\
\text { estimate herbage } \\
\text { mass at a paddock } \\
\text { scale and assist } \\
\text { management on } \\
\text { dairy farms }\end{array}$ & $\begin{array}{l}\text { Development of a } \\
\text { grass growth } \\
\text { model for New } \\
\text { Zealand pasture }\end{array}$ & $\begin{array}{l}\text { New } \\
\text { Zealand }\end{array}$ & PRG & $\begin{array}{l}\text { Grass } \\
\text { growth } \\
\text { model }\end{array}$ & 1 & Paddock \\
\hline $\begin{array}{l}\text { Herrmann } \\
\text { et al. [131] }\end{array}$ & 2005 & $\begin{array}{l}\text { Performance of } \\
\text { grassland under } \\
\text { different cutting } \\
\text { regimes as affected } \\
\text { by sward } \\
\text { composition, } \\
\text { nitrogen input, soil } \\
\text { conditions and } \\
\text { weather-A } \\
\text { simulation study }\end{array}$ & $\begin{array}{l}\text { Calibration of } \\
\text { forage growth and } \\
\text { quality model }\end{array}$ & Germany & PRG/WC/ & $\begin{array}{r}\text { Grass } \\
\text { ixed growth } \\
\text { model }\end{array}$ & 3 & Plot \\
\hline
\end{tabular}


Table A1. Cont.

\begin{tabular}{|c|c|c|c|c|c|c|c|c|}
\hline Study & Year & Title & Study Focus & Region & $\begin{array}{c}\text { Grass } \\
\text { Species }\end{array}$ & $\begin{array}{c}\text { Measurement } \\
\text { System }\end{array}$ & $\begin{array}{l}\text { No. of } \\
\text { Grazing } \\
\text { Seasons }\end{array}$ & $\begin{array}{l}\text { Trial } \\
\text { Scale }\end{array}$ \\
\hline $\begin{array}{l}\text { Murphy } \\
\text { et al. [132] }\end{array}$ & 2019 & $\begin{array}{l}\text { GrassQ-a holistic } \\
\text { precision grass } \\
\text { measurement and } \\
\text { analysis system to } \\
\text { optimize pasture } \\
\text { based livestock } \\
\text { production }\end{array}$ & $\begin{array}{l}\text { Development of } \\
\text { decision support } \\
\text { system to process } \\
\text { data from multiple } \\
\text { measurement } \\
\text { systems }\end{array}$ & Ireland & PRG & $\begin{array}{l}\text { RPM, Hyper- } \\
\text { spectral, } \\
\text { multispec- } \\
\text { tral }\end{array}$ & 2 & Paddock \\
\hline $\begin{array}{l}\text { O' Brien } \\
\text { et al. [133] }\end{array}$ & 2019 & $\begin{array}{l}\text { Modelling precision } \\
\text { grass measurements } \\
\text { for a web-based } \\
\text { decision platform to } \\
\text { aid grassland } \\
\text { management }\end{array}$ & $\begin{array}{l}\text { Development of } \\
\text { decision support } \\
\text { system to process } \\
\text { data from multiple } \\
\text { measurement } \\
\text { systems }\end{array}$ & Ireland & PRG & $\begin{array}{l}\text { RPM, Hyper- } \\
\text { spectral, } \\
\text { multispec- } \\
\text { tral }\end{array}$ & 2 & Paddock \\
\hline
\end{tabular}

$\mathrm{DM}=$ Dry matter, $\mathrm{PRG}=$ Perennial rye grass, $\mathrm{WC}=$ white clover, Paddock = predominately grazed pasture $>0.25$ ha, Plots $=$ simulated grazed plots $<0.25$ ha.

\section{References}

1. Herrero, M.; Wirsenius, S.; Henderson, B.; Rigolot, C.; Thornton, P.; Havlík, P.; De Boer, I.; Gerber, P.J. Livestock and the Environment: What Have We Learned in the Past Decade? Annu. Rev. Environ. Resour. 2015, 40, 177-202. [CrossRef]

2. Henchion, M.; Hayes, M.; Mullen, A.; Fenelon, M.; Tiwari, B. Future Protein Supply and Demand: Strategies and Factors Influencing a Sustainable Equilibrium. Foods 2017, 6, 53. [CrossRef] [PubMed]

3. Tilman, D.; Clark, M. Global diets link environmental sustainability and human health. Nature 2014, 515, 518-522. [CrossRef] [PubMed]

4. Huyghe, C.; De Vliegher, A.; Van Gils, B.; Peeters, A. Grasslands and Herbivore Production in Europe and Effects of Common Policies; Éditions Quae: Versailles, France, 2014. [CrossRef]

5. Hennessy, D.; Delaby, L.; van den Pol-van Dasselaar, A.; Shalloo, L. Increasing Grazing in Dairy Cow Milk Production Systems in Europe. Sustainability 2020, 12, 2443. [CrossRef]

6. Van den Pol-van Dasselaar, A.; Hennessy, D.; Isselstein, J. Grazing of dairy cows in europe-an in-depth analysis based on the perception of grassland experts. Sustainability 2020, 12, 1098. [CrossRef]

7. Hennessy, D.; Delaby, L.; Van den Pol-van Dasselaar, A.; Shalloo, L. Possibilities and constraints for grazing in high output dairy systems. In Proceedings of the 18th Symposium European Grassland Federation, Wageningen, The Netherland, 15-17 June 2015; Van den Pol-van Dasselaar, A., Aarts, H.F.M., De Vliegher, A., Elgersma, A., Reheul, D., Reijneveld, J.A., Verloop, J., Hopkins, A., Eds.; Wageningen Academic Publishers: Wageningen, The Netherlands, 2015; pp. 151-162.

8. Barthram, G.T.; Duff, E.I.; Elston, D.A.; Griffiths, J.H.; Common, T.G.; Marriott, C.A. Frequency distributions of sward height under sheep grazing. Grass Forage Sci. 2005, 60, 4-16. [CrossRef]

9. Klootwijk, C.W.; Holshof, G.; de Boer, I.J.; Van den Pol-Van Dasselaar, A.; Engel, B.; Van Middelaar, C.E. Correcting fresh grass allowance for rejected patches due to excreta in intensive grazing systems for dairy cows. J. Dairy Sci. 2019, 102, 10451-10459. [CrossRef]

10. Nakagami, K. A method for approximate on-farm estimation of herbage mass by using two assessments per pasture. Grass Forage Sci. 2016, 71, 490-496. [CrossRef]

11. O' Donovan, M.; Lewis, E.; O' Kiely, P. Requirements of future grass-based ruminant production systems in Ireland. Ir. J. Agric. Food Res. 2011, 50, 1-21.

12. Weiss, F.; Leip, A. Greenhouse gas emissions from the EU livestock sector: A life cycle assessment carried out with the CAPRI model. Agric. Ecosyst. Environ. 2012. [CrossRef]

13. O' Brien, D.; Capper, J.L.; Garnsworthy, P.C.; Grainger, C.; Shalloo, L. A case study of the carbon footprint of milk from high-performing confinement and grass-based dairy farms. J. Dairy Sci. 2014, 97, 1835-1851. [CrossRef]

14. McCarthy, J.; Delaby, L.; Hennessy, D.; McCarthy, B.; Ryan, W.; Pierce, K.; Brennan, A.; Horan, B. The effect of stocking rate on soil solution nitrate concentrations beneath a free-draining dairy production system in Ireland. J. Dairy Sci. 2015, 98, 4211-4224. [CrossRef]

15. Dentler, J.; Kiefer, L.; Hummler, T.; Bahrs, E.; Elsaesser, M. The impact of low-input grass-based and high-input confinement-based dairy systems on food production, environmental protection and resource use. Agroecol. Sustain. Food Syst. 2020. [CrossRef]

16. Wilkinson, J.M.; Lee, M.R.F.; Rivero, M.J.; Chamberlain, A.T. Some challenges and opportunities for grazing dairy cows on temperate pastures. Grass Forage Sci. 2020, 75, 1-17. [CrossRef]

17. Hanrahan, L.; McHugh, N.; Hennessy, T.; Moran, B.; Kearney, R.; Wallace, M.; Shalloo, L. Factors associated with profitability in pasture-based systems of milk production. J. Dairy Sci. 2018, 101, 5474-5485. [CrossRef] 
18. Finneran, E.; Crosson, P.; O' Kiely, P.; Shalloo, L.; Forristal, D.; Wallace, M. Stochastic simulation of the cost of home-produced feeds for ruminant livestock systems. J. Agric. Sci. 2012, 150, 123-139. [CrossRef]

19. Maher, J.; Bogue, F.; Douglas, J. Grass10 campaign. Moorepark. In Proceedings of the 19 Irish Dairy-Growing Sustainability, Moorepark, Fermoy, Teagasc, Ireland, 3 July 2019; pp. 62-64.

20. Hanrahan, L.; Geoghegan, A.; O’Donovan, M.; Griffith, V.; Ruelle, E.; Wallace, M.; Shalloo, L. PastureBase Ireland: A grassland decision support system and national database. Comput. Electron. Agric. 2017, 136, 193-201. [CrossRef]

21. Creighton, P.; Kennedy, E.; Shalloo, L.; Boland, T.; Donovan, M. A survey analysis of grassland dairy farming in Ireland, investigating grassland management, technology adoption and sward renewal. Grass Forage Sci. 2011, 66, 251-264. [CrossRef]

22. Beukes, P.C.; McCarthy, S.; Wims, C.M.; Gregorini, P.; Romera, A.J. Regular estimates of herbage mass can improve profitability of pasture-based dairy systems. Anim. Prod. Sci. 2019, 59, 359. [CrossRef]

23. Wilkinson, J.M.; Allen, J.D.; Tunnicliffe, R.; Smith, M.; Garnsworthy, P.C. Variation in composition of pre-grazed pasture herbage in the United Kingdom, 2006-2012. Anim. Feed. Sci. Technol. 2014, 196, 139-144. [CrossRef]

24. Shalloo, L.; Donovan, M.O.; Leso, L.; Werner, J.; Ruelle, E.; Geoghegan, A.; Delaby, L.; O’Leary, N. Review: Grass-based dairy systems, data and precision technologies. Animal 2018, 12, S262-S271. [CrossRef] [PubMed]

25. Dillon, P. Achieving high dry-matter intake from pasture with grazing dairy cows. In Fresh Herb. Dairy Cattle Key to a Sustainable Food Chain; Elgersma, A., Dijkstra, J., Tamminga, S., Eds.; Springer: New York, NY, USA, 2006; pp. 1-26. [CrossRef]

26. O' Donovan, M.; Dillon, P.; Rath, M.; Stakelum, G. A Comparison of Four Methods of Herbage Mass Estimation. Ir. J. Agric. Food Res. 2002, 41, 17-27.

27. Sanderson, M.A.; Rotz, C.A.; Fultz, S.W.; Rayburn, E.B. Estimating forage mass with a commercial capacitance meter, rising plate meter, and pasture ruler. Agron. J. 2001, 93, 1281-1286. [CrossRef]

28. Klootwijk, C.W.; Holshof, G.; Dasselaar, A.V.D.P.-V.; Van Helvoort, K.L.; Engel, B.; De Boer, I.J.; Van Middelaar, C.E. The effect of intensive grazing systems on the rising plate meter calibration for perennial ryegrass pastures. J. Dairy Sci. 2019, 102, 10439-10450. [CrossRef] [PubMed]

29. Murphy, D.J.; O’ Brien, B.; Hennessy, D.; Hurley, M.; Murphy, M.D. Evaluation of the precision of the rising plate meter for measuring compressed sward height on heterogeneous grassland swards. Precis. Agric. 2020. [CrossRef]

30. Burns, G.A.; Gilliland, T.J.; Grogan, D.; Watson, S.; O' Kiely, P. Assessment of herbage yield and quality traits of perennial ryegrasses from a national variety evaluation scheme. J. Agric. Sci. 2013, 151, 331-346. [CrossRef]

31. Schellberg, J.; Hill, M.J.; Gerhards, R.; Rothmund, M.; Braun, M. Precision agriculture on grassland: Applications, perspectives and constraints. Eur. J. Agron. 2008, 29, 59-71. [CrossRef]

32. Google. Google Scholar. 2021. Available online: https://scholar.google.com/ (accessed on 4 October 2016).

33. Elsevier. ScienceDirect. 2021. Available online: https:/ /www.sciencedirect.com/ (accessed on 4 October 2016).

34. Jordan, C.; Shi, Z.; Bailey, J.S.; Higgins, A.J. Sampling strategies for mapping "within-field" variability in the dry matter yield and mineral nutrient status of forage grass crops in cool temperate climes. Precis. Agric. 2003, 4, 69-86. [CrossRef]

35. Murphy, D.J.; O’ Brien, B.; Murphy, M.D. Development of a grass measurement optimisation tool to efficiently measure herbage mass on grazed pastures. Comput. Electron. Agric. 2020, 178. [CrossRef]

36. Stakelum, G.; Dillon, P. The effect of grazing pressure on rotationally grazed pastures in spring/early summer on subsequent sward characteristics. Ir. J. Agric. Food Res. 2007, 46, 15-28.

37. Enriquez-Hidalgo, D.; Egan, M.; Gilliland, T.; Lynch, M.B.; Hennessy, D. Grass-only and grass-white clover (Trifolium repens L.) swards: Dairy cow production. In Proceedings of the 25th General Meeting of the European Grassland Federation, Aberystwyth, Wales, 7-11 September 2014; Hopkins, A., Collins, R.P., Fraser, M.D., King, V.R., Lloyd, D.C., Moorby, J.M., Robson, P.R.H., Eds.; pp. 789-791.

38. O'Donovan, M.; Delaby, L. Grazed grass in the dairy cow diet-How this can be achieved better! In Proceedings of the 26th General Meeting of the European Grassland Federation Trondheim, Trondheim, Norway, 4-8 September 2016; Höglind, M., Bakken, A.K., Hovstad, K.A., Kallioniemi, E., Riley, H., Steinshamn, H., Østrem, L., Eds.; pp. 350-365.

39. Höglind, F.-L. Growing point dynamics and spring growth of white clover in a mixed sward and the effects of nitrogen application. Grass Forage Sci. 1998, 53, 338-345. [CrossRef]

40. Moloney, T.; Sheridan, H.; Grant, J.; O' Riordan, E.G.; O' Kiely, P. Yield of binary- and multi-species swards relative to single-species swards in intensive silage systems. Ir. J. Agric. Food Res. 2020, 59, 12-26. [CrossRef]

41. Beecher, M.; Hennessy, D.; Boland, T.M.; McEvoy, M.; O’Donovan, M.; Lewis, E. The variation in morphology of perennial ryegrass cultivars throughout the grazing season and effects on organic matter digestibility. Grass Forage Sci. 2015, 70, 19-29. [CrossRef]

42. Martin, R.C.; Astatkie, T.; Cooper, J.M.; Fredeen, A.H. A Comparison of Methods Used to Determine Biomass on Naturalized Swards. J. Agron. Crop. Sci. 2005, 191, 152-160. [CrossRef]

43. Cayley, J.W.D.; Bird, P.R. Techniques for Measuring Pastures; Victoria Dept of Agriculture, Energy and Minerals: Hamilton, Australia, 1996; Volume 2. [CrossRef]

44. Mannetje, L.T. Field and laboratory methods for grassland and animal production research. In Measuring Biomass of Grassland Vegetation; Mannetje, L.T., Jones, R.M., Eds.; CABI Publishing: Oxon, UK, 2000; pp. 151-178.

45. Thomson, N.A. Factors influencing the accuracy of herbage mass determinations with a capacitance meter. N. Z. J. Exp. Agric. 1983, 11, 171-176. [CrossRef] 
46. Earle, D.F.; Mc Gowan, A.A. Evaluation and calibration of an automated rising plate meter for estimating dry matter yield of pasture. Aust. J. Exp. Agric. 1979, 19, 337-343. [CrossRef]

47. Ferraro, F.P.; Nave, R.L.G.; Sulc, R.M.; Barker, D.J. Seasonal variation in the rising plate meter calibration for forage mass. Agron. J. 2012, 104, 1-6. [CrossRef]

48. O' Donovan, M.; Connolly, J.; Dillon, P.; Rath, M.; Stakelum, G. Visual Assessment of Herbage Mass. J. Agric. Food Res. 2002, 41, 201-211.

49. Campbell, N.A. The visual assessment of pasture yield. Aust. J. Exp. Agric. 1973, 13, 263-267. [CrossRef]

50. Stockdale, C.R. Evaluation of techniques for estimating the yield of irrigated pastures intensively grazed by dairy cows 1 . Visual assessment. Aust. J. Exp. Agric. Anim. Husb. 1984, 24, 300-304. [CrossRef]

51. L'Huillier, P.J.; Thomson, N.A. Estimation of herbage mass in ryegrass/white clover dairy pastures. J. N. Z. Grassl. 1988, 49, 117-139. [CrossRef]

52. Thomson, N.A.; Mccallum, D.A.; Howse, S.; Holmes, C.W.; Matthews, P.N.P.; Matthew, C. Estimation of dairy pastures-the need for standardisation. J. N. Z. Grassl. 1997, 59, 221-225.

53. Lile, J.; Blackwell, M.; Thomson, N.; Penno, J.; Macdonald, K.; Nicholas, P.; Lancaster, J.; Coulter, M. Practical use of the rising plate meter (RPM) on New Zealand dairy farms. J. N. Z. Grassl. 2001, 63, 159-164. [CrossRef]

54. O' Sullivan, M.; O' Keeffe, W.F.; Flynn, M.J. The Value of Pasture Height in the Measurement of Dry Matter Yield. Ir. J. Agric. Res. 1987, 26, 63-68.

55. McSweeney, D.; Coughlan, N.E.; Cuthbert, R.N.; Halton, P.; Ivanov, S. Micro-sonic sensor technology enables enhanced grass height measurement by a Rising Plate Meter. Inf. Process. Agric. 2019, 6, 279-284. [CrossRef]

56. Defrance, P.; Delaby, L.; Seuret, J.M. Mieux connaître la densité de l'herbe pour calculer la croissance, la biomasse d'une parcelle et le stock d'herbe disponible d'une exploitation. In Proceedings of the Rencontres Autour des Rech. sur les Ruminants, INRAE, Paris, France, 8 December 2004; pp. 291-294.

57. Holshof, G.; Stienezen, M.; Galama, P. Calibration of five rising plate meters in the Netherlands. In Proceedings of the 18th Symposium of the European Grassland Federation, Wageningen, The Netherlands, 15-17 June 2015; Van den Pol-van Dasselaar, A., Aarts, H.F.M., Vliegher, A., De Elgersma, A., Reheul, D., Reijneveld, J.A., Verloop, J., Hopkins, A., Eds.; Wageningen Academic Publishers: Wageningen, The Netherlands, 2015; pp. 233-235.

58. De Alckmin, T.G.; Kooistra, L.; Rawnsley, R.; Lucieer, A. Comparing methods to estimate perennial ryegrass biomass: Canopy height and spectral vegetation indices. Precis. Agric. 2020, 205-225. [CrossRef]

59. Murphy, D.J.; Shine, P.; O’ Brien, B.; O’ Donovan, M.; Murphy, M.D. Utilising grassland management and climate data for more accurate prediction of herbage mass using the rising plate meter. Precis Agric. 2021. [CrossRef]

60. Mannetje, L.T. Advances in grassland science. Neth. J. Agric. Sci. 2002, 50, 195-222. [CrossRef]

61. Mawby, W.D. Make Your Destructive, Dynamic, and Attribute Measurement System Work for You; ASQ Quality Press: Milwaukee, WI, USA, 2006

62. Webster, R.; Lark, R.M. Field Sampling for Environmental Science and Management; Routledge: Oxon, UK, 2012.

63. Deming, J.; Gleeson, D.; O' Dwyer, T.; Kinsella, J.; O' Brien, B. Measuring labor input on pasture-based dairy farms using a smartphone. J. Dairy Sci. 2018, 101, 9527-9543. [CrossRef]

64. Hall, A.; Turner, L.; Kilpatrick, S. Understanding Tasmanian dairy farmer adoption of pasture management practices: A Theory of Planned Behaviour approach. Anim. Prod. Sci. 2019, 59, 1941-1950. [CrossRef]

65. Eastwood, C.; Dela Rue, B.; Kerslake, J. Developing an approach to assess farmer perceptions of the value of pasture assessment technologies. Grass Forage Sci. 2020, 75, 474-485. [CrossRef]

66. Hutchinson, K.; Scobie, D.; Beautrais, J.; Mackay, A.; Rennie, G.; Moss, R.; Dynes, R. A protocol for sampling pastures in hill country. J. N. Z. Grassl. 2016, 78, 203-210. [CrossRef]

67. Delmelle, E. Spatial Sampling. In Handbook of Applied Spatial Analysis; Fotheringham, A.S., Rogerson, P.A., Eds.; SAGE: Los Angeles, CA, USA, 2009; pp. 165-186.

68. Bernardi, A.C.C.; Bettiol, G.M.; Ferreira, R.P.; Santos, K.E.L.; Rabello, L.M.; Inamasu, R.Y. Spatial variability of soil properties and yield of a grazed alfalfa pasture in Brazil. Precis. Agric. 2016, 17, 737-752. [CrossRef]

69. Higgins, S.; Bailey, J.S. The role of precision agriculture in optimising soil nutrient status and grassland productivity in Northern Ireland, while reducing nutrient losses to air or water. In Science Policy: Nutrient Management Challenges for the Next Generation; Currie, L.D., Hedley, M.J., Eds.; Massey University: Palmerston North, New Zealand, 2017.

70. Posudin, Y.I. Practical Spectroscopy in Agriculture and Food Science; Science Publishers: Enfield, NH, USA, 2007.

71. NIRS Forage and Feed Testing Consortium. NIRS White Paper. 2008. Available online: http://www.uwex.edu/ces/forage/ NIRS/home-page.htm (accessed on 5 June 2020).

72. De Boever, J.L.; Cottyn, B.G.; Vanacker, J.M.; Boucqué, C.V. The use of NIRS to predict the chemical composition and the energy value of compound feeds for cattle. Anim. Feed. Sci. Technol. 1995, 51, 243-253. [CrossRef]

73. Norris, K.H.; Barnes, R.F.; Moore, J.E.; Shenk, J.S. Predicting Forage Quality by Infrared Reflectance Spectroscopy. J. Anim. Sci. 1976, 43, 889-897. [CrossRef]

74. Lahart, B.; McParland, S.; Kennedy, E.; Boland, T.M.; Condon, T.; Williams, M.; Galvin, N.; McCarthy, B.; Buckley, F. Predicting the dry matter intake of grazing dairy cows using infrared reflectance spectroscopy analysis. J. Dairy Sci. 2019, 102, 8907-8918. [CrossRef] 
75. Jafari, A.; Connolly, V.; Frolich, A.; Walsh, E.J. A Note on Estimation of Quality Parameters in Perennial Ryegrass by near Infrared. Ir. J. Agric. Food Res. 2003, 42, 293-299.

76. Burns, G.A.; O' Kiely, P.; Grogan, D.; Gilliland, T.J. A note on the comparison of three near infrared reflectance spectroscopy calibration strategies for assessing herbage quality of ryegrass. Ir. J. Agric. Food Res. 2014, 53, 199-204.

77. Alomar, D.; Fuchslocher, R.; De Pablo, M. Effect of preparation method on composition and NIR spectra of forage samples. Anim. Feed. Sci Technol. 2003, 107, 191-200. [CrossRef]

78. McClure, W.F.; Crowell, B.; Stanfield, D.L.; Mohapatra, S.; Morimoto, S.; Batten, G. Near infrared technology for precision environmental measurements: Part 1. Determination of nitrogen in green- and dry-grass tissue. J. Near Infrared Spectrosc. 2002. [CrossRef]

79. Reddersen, B.; Fricke, T.; Wachendorf, M. Effects of sample preparation and measurement standardization on the NIRS calibration quality of nitrogen, ash and NDFom content in extensive experimental grassland biomass. Anim. Feed. Sci. Technol. 2013, 183, 77-85. [CrossRef]

80. Thomson, A.L.; Humphries, D.J.; Rymer, C.; Archer, J.E.; Grant, N.W.; Reynolds, C.K. Assessing the accuracy of current near infra-red reflectance spectroscopy analysis for fresh grass-clover mixture silages and development of new equations for this purpose. Anim. Feed. Sci. Technol. 2018, 239, 94-106. [CrossRef]

81. Alomar, D.; Fuchslocher, R.; Cuevas, J.; Mardones, R.; Cuevas, E. Prediction of the composition of fresh pastures by near infrared reflectance or interactance-reflectance spectroscopy. Chil. J. Agric. Res. 2009, 69, 198-206. [CrossRef]

82. Dale, A.J.; Gordon, A.W.; Archer, J.; Ferris, C.P. Impact of sampling and storage technique, and duration of storage, on the composition of fresh grass when analysed using near-infrared reflectance spectroscopy. Grass Forage Sci. 2017, 72, 614-625. [CrossRef]

83. Lobos, I.; Moscoso, C.J.; Pavez, P. Calibration models for the nutritional quality of fresh pastures by near-infrared reflectance spectroscopy. Cience Investig. Agrar. 2019, 46, 234-242. [CrossRef]

84. Murphy, D.J.; O’ Brien, B.; O' Donovan, M.; Condon, T.; Murphy, M.D. A near infrared spectroscopy calibration for the prediction of fresh grass quality on Irish pastures. Inf. Process. Agric. 2021. [CrossRef]

85. Berzaghi, P.; Serva, L.; Piombino, M.; Mirisola, M.; Benozzo, F. Prediction performances of portable near infrared instruments for at farm forage analysis. Ital. J. Anim. Sci. 2005, 4, 145-147. [CrossRef]

86. Dos Santos, T.C.A.; Lopo, M.; Páscoa, R.N.M.J.; Lopes, J.A. A review on the applications of portable near-infrared spectrometers in the agro-food industry. Appl. Spectrosc. 2013, 67, 1215-1233. [CrossRef]

87. Feuerstein, U.; Paul, C. NIR-Spectroscopy of non-dried forages as a tool in breeding for higher quality-laboratory tests and online investigations on plot harvesters. In Proceedings of the XXVIIth EUCARPIA Symposium on Improvement of Fodder Crops and Amenity Grasses, Copenhagen, Denmark, 19-23 August 2007; Lübberstedt, T., Studer, B., Graugaard, S., Eds.; European Association for Research on Plant Breeding: Wageningen, The Netherlands, 2007; pp. 110-114.

88. Mendarte, S.; Ibarra, A.; Garbisu, C.; Besga, G. Use of portable NIRS equipment in field conditions to determine the nutritional value of mountain pastures. In Proceedings of the 23th General Meeting of the European Grassland Federation, Kiel, Germany, 29 August-2 September 2010; Schnyder, H., Isselstein, J., Taube, F., Auerswald, K., Schellberg, J., Wachendorf, M., Herrmann, A., Gierus, M., Wrage, N., Hopkins, A., Eds.; pp. 244-246.

89. Smith, C.; Karunaratne, S.; Badenhorst, P.; Cogan, N.; Spangenberg, G.; Smith, K. Machine learning algorithms to predict forage nutritive value of in situ perennial ryegrass plants using hyperspectral canopy reflectance data. Remote Sens. 2020, 12, 928. [CrossRef]

90. Bell, M.J.; Mereu, L.; Davis, J. The Use of Mobile Near-Infrared Spectroscopy for Real-Time Pasture Management. Front. Sustain. Food Syst. 2018, 2, 76. [CrossRef]

91. Patton, L.; McConnell, D.; Archer, J.; O' Donovan, M.; Gilliland, T. Portable NIRS: A novel technology for the prediction of forage nutritive quality. In Proceedings of the General Meeting of the European Grassland Federation, Moorepark, Cork, Ireland, 17-21 June 2018; Hennessy, D., O’Donovan, M., Kennedy, E., McCarthy, B., Finn, J.A., O’Brien, B., Eds.; pp. $892-894$.

92. Hart, L.; Huguenin-Elie, O.; Latsch, R.; Simmler, M.; Dubois, S.; Umstatter, C. Comparison of Spectral Reflectance-Based Smart Farming Tools and a Conventional Approach to Determine Herbage Mass and Grass Quality on Farm. Remote Sens. 2020, 12, 3256. [CrossRef]

93. Vogel, S.; Gebbers, R.; Oertel, M.; Kramer, E. Evaluating Soil-Borne Causes of Biomass Variability in Grassland by Remote and Proximal Sensing. Sensors 2019, 19, 4593. [CrossRef] [PubMed]

94. Reddersen, B.; Fricke, T.; Wachendorf, M. A multi-sensor approach for predicting biomass of extensively managed grassland. Comput. Electron. Agric. 2014, 109, 247-260. [CrossRef]

95. Fricke, T.; Richter, F.; Wachendorf, M. Assessment of forage mass from grassland swards by height measurement using an ultrasonic sensor. Comput. Electron. Agric. 2011, 79, 142-152. [CrossRef]

96. Safari, H.; Fricke, T.; Reddersen, B.; Möckel, T.; Wachendorf, M. Comparing mobile and static assessment of biomass in heterogeneous grassland with a multi-sensor system. J. Sens. Sens. Syst. 2016, 5, 301-312. [CrossRef]

97. Moeckel, T.; Safari, H.; Reddersen, B.; Fricke, T.; Wachendorf, M. Fusion of Ultrasonic and Spectral Sensor Data for Improving the Estimation of Biomass in Grasslands with Heterogeneous Sward Structure. Remote Sens. 2017, 9, 98. [CrossRef]

98. Legg, M.; Bradley, S. remote sensing Ultrasonic Proximal Sensing of Pasture Biomass. Remote Sens. 2019, 11, 2459. [CrossRef] 
99. Rennie, G.M.; King, W.M.; Puha, M.R.; Dalley, D.E.; Dynes, R.A.; Upsdell, M.P. Calibration of the C-DAX Rapid Pasturemeter and the rising plate meter for kikuyu-based Northland dairy pastures. J. N. Z. Grassl. 2009, 71, 49-55. [CrossRef]

100. Lawrence, H.; Yule, I.; Murray, R. Pasture Monitoring Technologies. In Proceedings of the South Island Dairy Event Conference 8, South Island Dairy Event, Lincoln, New Zealand, 20 June 2007; pp. 126-131.

101. King, W.M.; Rennie, G.M.; Dalley, D.E.; Dynes, R.A.; Upsdell, M.P. Pasture Mass Estimation by the C-DAX Pasture Meter: Regional Calibrations for New Zealand. In Proceedings of the 4th Australasain Dairy Science Symposium 2010, Lincoln University, Lincoln, New Zealand, 31 August-2 September 2010; The New Zealand Veterinary Association: Wellington, New Zealand, 2010; pp. 233-238.

102. Oudshoorn, F.W.; Hansson, S.L.; Hansen, H.H. Calibration of the C-dax pasture meter in a Danish grazing system. In Proceedings of the 16th Symposium of the European Grassland Federation, Gumpenstein, Austria, 29-31 August 2011; Pötsch, E.M., Krautzer, B., Hopkins, A., Eds.; Agricultural Research and Education Centre (AREC): Irdning, Austria, 2011; pp. $166-168$.

103. Schori, F. Sward surface height estimation with a rising plate meter and the C-Dax Pasturemeter. In Proceedings of the 18th Symposium of the European Grassland Federation, Wageningen, The Netherlands, 15-17 June 2015; Dasselaar, A.v.d.P., Aarts, H.F.M., Vliegher ADe Elgersma, A., Reheul, D., Reijneveld, J.A., Verloop, J., Hopkins, A., Eds.; The Nederlandse Vereniging voor Weide- en Voederbouw: Wageningen, The Netherlands, 2015; pp. 310-312.

104. Dennis, S.J.; Taylor, A.L.; O’Neill, K.; Clarke-Hill, W.; Dynes, R.A.; Cox, N.; Van Koten, C.; Jowett, T.W.D. Pasture yield mapping: Why \& how. J. N. Z. Grassl. 2015, 77, 41-46.

105. Manderson, A.; Hunt, C. Introducing the Agri-Rover: An Autonomous on-the-go sensing rover for science and farming. In Proceedings of the 26th Annual Farmed Landscapes Research Centre Workshop, Palmerston North, New Zealand, 12-14 February; Currie, L., Christensen, C.L., Eds.; Massey University: Palmerston North, New Zealand, 2013.

106. Gobor, Z.; Cariou, C.; Seiferth, B.; Thurner, S.; Feucker, W.; Tessier, C.; Tekin, B.; Berducat, M. Advanced pasture management through innovative robotic pasture maintenance. In Proceedings of the IROS Workshop Agri-Food Robot, Hambourg, Germany, 2 October 2015; Kootstra, G., Edan, Y., Henten, E.v.B.M., Eds.; HAL: Lyon, France, 2015. [CrossRef]

107. Marín, J.; Parra, L.; Rocher, J.; Sendra, S.; Lloret, J.; Mauri, P.V.; Masaguer, A. Urban Lawn Monitoring in Smart City Environments. J. Sens. 2018, 2018. [CrossRef]

108. Rueda-Ayala, V.; Peña, J.; Höglind, M.; Bengochea-Guevara, J.; Andújar, D. Comparing UAV-Based Technologies and RGB-D Reconstruction Methods for Plant Height and Biomass Monitoring on Grass Ley. Sensors 2019, 19, 535. [CrossRef]

109. Rossel, V.R.A.; Adamchuk, V.I.; Sudduth, K.A.; McKenzie, N.J.; Lobsey, C. Proximal Soil Sensing: An Effective Approach for Soil Measurements in Space and Time. In Advances in Agronomy; Sparks, D.L., Ed.; Elsevier: Amsterdam, The Netherlands, 2011; Volume 113, pp. 243-291. [CrossRef]

110. Pullanagari, R.R.; Yule, I.J.; Tuohy, M.P.; Hedley, M.J.; Dynes, R.A.; King, W.M. In-field hyperspectral proximal sensing for estimating quality parameters of mixed pasture. Precis. Agric. 2012, 13, 351-369. [CrossRef]

111. Ancin-Murguzur, F.; Taff, G.; Davids, C.; Tømmervik, H.; Mølmann, J.; Jørgensen, M. Yield Estimates by a Two-Step Approach Using Hyperspectral Methods in Grasslands at High Latitudes. Remote Sens. 2019, 11, 400. [CrossRef]

112. Pullanagari, R.R.; Yule, I.J.; Tuohy, M.; Dynes, R.; King, W. Pasture Quailty Measurement Tools for Decsion Making 2011. Available online: https://www.massey.ac.nz/ \{\}flrc/workshops/11/Manuscripts/Pullanagari_2011.pdf (accessed on 21 June 2020).

113. Askari, M.S.; McCarthy, T.; Magee, A.; Murphy, D.J. Evaluation of Grass Quality under Different Soil Management Scenarios Using Remote Sensing Techniques. Remote Sens. 2019, 11, 1835. [CrossRef]

114. Capolupo, A.; Kooistra, L.; Berendonk, C.; Boccia, L.; Suomalainen, J. Estimating Plant Traits of Grasslands from UAV-Acquired Hyperspectral Images: A Comparison of Statistical Approaches. ISPRS Int. J. Geo Inf. 2015, 4, 2792-2820. [CrossRef]

115. Pullanagari, R.R.; Yule, I.J.; Tuohy, M.P.; Hedley, M.J.; Dynes, R.A.; King, W.M. Proximal sensing of the seasonal variability of pasture nutritive value using multispectral radiometry. Grass Forage Sci. 2012, 68, 110-119. [CrossRef]

116. Oliveira, R.A.; Näsi, R.; Niemeläinen, O.; Nyholm, L.; Alhonoja, K.; Kaivosoja, J.; Jauhiainen, L.; Viljanen, N.; Nezami, S.; Markelin, L.; et al. Machine learning estimators for the quantity and quality of grass swards used for silage production using drone-based imaging spectrometry and photogrammetry. Remote Sens. Environ. 2020, 246, 111830. [CrossRef]

117. Obanawa, H.; Yoshitoshi, R.; Watanabe, N.; Sakanoue, S. Portable LiDAR-Based Method for Improvement of Grass Height Measurement Accuracy: Comparison with SfM Methods. Sensors 2020, 20, 4809. [CrossRef]

118. Vázquez-Arellano, M.; Griepentrog, H.W.; Reiser, D.; Paraforos, D.S. 3-D Imaging Systems for Agricultural Applications-A Review. Sensors 2016, 16, 618. [CrossRef]

119. Cooper, S.D.; Roy, D.P.; Schaaf, C.B.; Paynter, I. Examination of the potential of terrestrial laser scanning and structure-from-motion photogrammetry for rapid nondestructive field measurement of grass biomass. Remote Sens. 2017, 9, 531. [CrossRef]

120. Sibanda, M.; Mutanga, O.; Rouget, M. Comparing the spectral settings of the new generation broad and narrow band sensors in estimating biomass of native grasses grown under different management practices. GISci. Remote Sens. 2016, 53, 614-633. [CrossRef]

121. ESA. Sentinel-2 2020. Available online: https:/ / sentinel.esa.int/web/sentinel/missions/sentinel-2 (accessed on 22 June 2020).

122. Barrett, B.; Nitze, I.; Green, S.; Cawkwell, F. Assessment of multi-temporal, multi-sensor radar and ancillary spatial data for grasslands monitoring in Ireland using machine learning approaches. Remote Sens. Environ. 2014, 152, 109-124. [CrossRef] 
123. Ali, I.; Barrett, B.; Cawkwell, F.; Green, S.; Dwyer, E.; Neumann, M. Application of Repeat-Pass TerraSAR-X Staring Spotlight Interferometric Coherence to Monitor Pasture Biophysical Parameters: Limitations and Sensitivity Analysis. IEEE J. Sel. Top. Appl. Earth Obs. Remote Sens. 2017, 10, 3225-3231. [CrossRef]

124. Delaby, L.; Duboc, G.; Cloet, E.; Martinot, Y. Pastur'Plan: A dynamic tool to support grazing management decision making in a rotational grazing system. In Proceedings of the 18th Symposium of the European Grassland Federation, Wageningen, The Netherlands, 15-17 June 2015; Van den Pol-van Dasselaar, A., Aarts, H.F.M., Vliegher, A., De Elgersma, A., Reheul, D., Reijneveld, J.A., Verloop, J., Hopkins, A., Eds.; pp. 200-202.

125. Zom, R.L.G.; Holshof, G. GrazeVision: A versatile grazing decision support model. In Proceedings of the 16th Symposium of the European Grassland Federation, Organising Committee of the 16th Symposium of the European Grassland Federation 2011 and Agricultural Research and Education Centre, Raumberg-Gumpenstein, Austria, 28-31 August 2011; Pötsch, E.M., Krautzer, B., Hopkins, A., Eds.; pp. 226-228.

126. Byrne, N.; Gilliland, T.J.; Mchugh, N.; Delaby, L.; Geoghegan, A.; O'donovan, M. Establishing phenotypic performance of grass varieties on Irish grassland farms. J. Agric. Sci. 2017, 155, 1633-1645. [CrossRef]

127. O' Leary, M.; O' Donovan, M. PastureBase Ireland—getting Ireland utilising more grass. In Proceedings of the Moorepark '19 Irish Dairy—Growing Sustainability, Teagasc, Moorepark, Ireland, 3 July 2019; pp. 60-61.

128. McDonnell, J.; Brophy, C.; Ruelle, E.; Shalloo, L.; Lambkin, K.; Hennessy, D. Weather forecasts to enhance an Irish grass growth model. Eur. J. Agron. 2019, 105, 168-175. [CrossRef]

129. Ruelle, E.; Hennessy, D.; Delaby, L. Development of the Moorepark St Gilles grass growth model (MoSt GG model): A predictive model for grass growth for pasture based systems. Eur. J. Agron. 2018, 99, 80-91. [CrossRef]

130. Romera, A.J.; Beukes, P.; Clark, C.; Clark, D.; Levy, H.; Tait, A. Use of a pasture growth model to estimate herbage mass at a paddock scale and assist management on dairy farms. Comput. Electron. Agric. 2010, 74, 66-72. [CrossRef]

131. Herrmann, A.; Kelm, M.; Kornher, A.; Taube, F. Performance of grassland under different cutting regimes as affected by sward composition, nitrogen input, soil conditions and weather-A simulation study. Eur. J. Agron. 2005, 22, 141-158. [CrossRef]

132. Murphy, D.J.; O’Brien, B.; Askari, M.S.; McCarthy, T.; Magee, A.; Burke, R.; Murphy, M.D. GrassQ—a holistic precision grass measurement and analysis system to optimize pasture based livestock production. In Proceedings of the ASABE Annual Interantional Meeting, American Society of Agricultural and Biological Engineers, St. Joseph, MI, USA, 7-10 July 2019; pp. 2-9. [CrossRef]

133. O’Brien, B.; Murphy, D.; Askari, M.S.; Burke, R.; Magee, A.; Umstätter, C.; Hart, L.; Oudshoorn, F.; Murphy, M.; Kaivosoja, J.; et al. Modelling precision grass measurements for a web-based decision platform to aid grassland management. In Proceedings of the 9th European Conference on Precision Livestock Farming, Moorepark, Cork, Ireland, 26-29 August 2019; O’Brien, B., Hennessy, D., Shalloo, L., Eds.; Teagasc, Animal \& Grassland Research and Innovation Centre: Fermoy, Ireland, 2015 ; pp. 858-863. 